Petar Radanliev

Architectures for Green-Field Supply Chain Integration

Supply Chain Integration Design

\title{
Architectures for Green-Field Supply Chain Integration Supply Chain Integration Design
}

\author{
Petar Radanliev* \\ Oxford E - Research Centre, Oxford University, 7 Keble Road, Oxford, OX1 3QG, United \\ Kingdom \\ petar.radanliev@oerc.ox.ac.uk
}

This paper applied case study research to design architectures for green-field supply chain integration. The integration design is based on a case study of a supply chain integration of 5 companies, operating in different, but supply chain complimenting industry sectors. The case study research is applied to design and validate the architectures in a real world scenario. The supply chain integration architectures enable the conversion of individual into integrated strategies. The architectures are categorised and the process develops into a conceptual system for identifying the correlations between individual participants' strategic areas of interest and the integrated supply chain areas of interest. The novelty of this paper is a conceptual system for green-field supply chain integration architectures, which can be applied in real world by supply chain practitioners.

* Corresponding Author. E-mail address: petar.radanliev@oerc.ox.ac.uk

\section{INTRODUCTION}

\subsection{Background and Rationale}

The supply chain focus is shifting towards integration and collaboration, but collaboration is still focused on company profitability and not supply chain profitability (Kim, 2006, Radanliev, 2015, Radanliev, 2016). A 'paradigm shift' has been proposed (Kim, 2006) based on trust, equitable win-win thinking and sharing of key resources and core competences between the supply chain participants. The 'process chain' paradigm, recommends elements for process reengineering. However, the paradigm falls short of providing the details for applying these recommendations. The notion of the proposed paradigm shift through 'process chain' is admirable, however, other literature on the topic advocates a less radical approach and recommends incremental approaches for 'gradually and systematically' integrating the structure of the entire supply chain simultaneously (Narasimhan and Kim, 2002, pp. 320). Strategies that are designed and formulated with a singular focus on integration and performance, such as Frohlich and Westbrook (2001), lead to many questions regarding other aspects of supply chain strategy. Several authors identified limitations in this approach (Rosenzweig et al., 2003, Perez-Franco et al., 2010, Childerhouse and Towill, 2011), because various supply chain aspects should be considered in the design and formulation stage to ensure a wide coverage. Each type of supply chain integration activity has a unique set of benefits and additional study of the external strategic integration activities is required (Swink et al., 2007). 


\section{Petar Radanliev \\ Architectures for Green-Field Supply Chain Integration \\ Supply Chain Integration Design}

\subsection{Research Objectives}

The aim of this paper is to design conceptual architectures for green-field (new and non-existent as opposed to reformulating existing supply chains) supply chain formulation and integration.

The first objective is to design a set of architectures for categorising individual into integrated business strategies, through systematically grouping individual areas of business interests. The second objective is to advance the individual architectures into integration design with a consistent set of interrelated ideas and interworking set of objectives that would support and enable the integrated business strategy. The third objective is to design a conceptual system for green-field supply chain integration architecture and to resolve business problems emerging from the supply chain integration. The objective is to perceive the supply chain as a system. Where the complexity of the system is determined by the supply chain elements and the elements are segregated in clear and easy to replicate categories and to derive with a process for simplifying the complex elements.

\section{LITERATURE REVIEW}

A supply chain is defined as a complex adaptive system (Bozarth et al., 2009, Pathak et al., 2007), a single entity system or a confederation (Mentzer et al., 2001), and a networked organisation (Ivanov, 2009). Supply chain design is defined as a consistent interlinking of architecture and design, through focusing on the external and salient dimensions and internal elements, which are system germane to the supply chain (Melnyk et al., 2013). The focus of the paper is on the supply chain architecture aspect and distinguishes the topic from supply chain management. In this context, the focus of the paper is on the integration of green-field supply chain architectures.
Supply chain architecture is integrated to the business model (Martínez-Olvera and Shunk, 2006). Greater integration lead to better performance (Swink et al., 2007, Narasimhan and Kim, 2002) and effectiveness (Kim, 2006). The supply chain is effectively a result of internal and external integration (Saad et al., 2002) while outsourcing creates a number of negative effects (Gilley and Rasheed, 2000), and greater collective operational activities need to be advanced through integration (Childerhouse and Towill, 2011, Rosenzweig et al., 2003, Frohlich and Westbrook, 2001).

Different types of supply chain integration create different effect (He and Lai, 2012) and companies should be seeking the right level and form that optimises the performance (Jayaram and Tan, 2010), emphasising the need for communication exchange mechanisms (Prajogo and Olhager, 2012).

Nikulin et al. (2013) described an operative algorithm for integration strategy, while Melnyk et al. (2013) proposed a framework for understanding supply chain design by following the key level factors. However, those studied followed the path of many authors in the past and ignored, the Van der Vaart and van Donk (2008) recommendations by constructing a limited measurement and ignoring the vast list of measurements in existing literature. To address this problem, this paper investigates how supply chain integration strategy could embrace a new vision of collaborative commerce and synchronisation of supply chain information flow, promoting flexibility and effectiveness (Kim, 2006, Frohlich and Westbrook, 2001, Vickery et al., 2003, Manthou et al., 2004, AlMudimigh et al., 2004).

Supply chain strategy and competitive strategy are commonly not linked to the corporate strategy (Mckone et al., 2009) and challenges still remain in the processes for adapting and aligning supply chain principles (Saad et al., 2002) and operations (Sakka et al., 


\section{Petar Radanliev \\ Architectures for Green-Field Supply Chain Integration \\ Supply Chain Integration Design}

2011). This leads to the conclusion that the supply chain architecture topic remains inconclusive and further research is needed to develop demystify this topic (Mckone et al., 2009, Saad et al., 2002, Sakka et al., 2011). Such design architectures benefit from being tested with real world case study research (Martínez-Olvera and Shunk, 2006, MartínezOlvera, 2008, Narasimhan et al., 2008, PerezFranco et al., 2010, Nikulin et al. 2013, Melnyk et al. 2013). This paper aims to address this gap in literature because supply chain architectures require integration of information and physical flows of all participants in the supply chain (Bozarth et al., 2009).

\section{RESEARCH METHODOLOGY}

For green-field project supply chain architecture to be formulated and integrated in the form of a networked organisation, the supply chain participants need to combine and integrate their operational activities as a single entity (Radanliev, 2014). To achieve such integration, this paper applied case study research to identify the relationship between individual participants' goals (sum of grouped individual strategic principles - $\mathrm{CN} . \mathrm{PN}$ ) and areas of interest (areas of decision/areas of problems - AD) The areas of interest represent an attempt to define areas of integration that provide means for achieving the ( $\left.\mathrm{CN}_{\mathrm{N}} \mathrm{PN}\right)$ and ensure the successful integration of the individual strategic visions - $(\mathrm{SCCNPN})$ and (CN.PN) through assembling the conceptual supply chain strategy as a system of concepts. The relationships between the goals and integration areas is evaluated through categorising the interests as formulation areas and strategic decisions related to integration as formulation principles that are later segregated into sub-categories of formulation imperatives.

The relationship between the formulation areas and principles is investigated in relation to integration. In the process, to support and validate the findings, case study research was applied combined with internal and external documents reviews. The resulting framework is generalised for conceptual formulation to present a valid method for investigation of the relationships between business and supply chain strategy in the context of integration and green-field project formulation. The formulation areas required engaging with the participants to identify linkages between the individual companies' $\left(\mathrm{CN} . \mathrm{PN}_{\mathrm{N}}\right)$ representing an opportunity for all the participants to imprint their (AD) in the integration.

\subsection{Categorizing Individual Goals into Formulation Areas}

The integrated individual (AD) and $(\mathrm{SCCNPN})$ represented in the integrated strategic vision - (ISV) and the integrated principles of the supply chain - (IPN) are built into concept diagrams Fig. 1 that summarise the green-field supply chain architecture. The conceptual diagram represents explicitly and easily identifiable (ISV) and (ADN) in Fig. 1. The process is required for the architecture to:

a) Evaluate the goals of multiple individual participants from the sum of grouped individual strategic goals (CN.PN)

b) Extract $(\mathrm{ADN})$ from the ideas behind (CN.PN)

c) Categorise goals in the form of areas of decision/areas of problems (AD)

d) Evaluate whether the (ADN) are supportive of individual strategic pillars $(\mathrm{SCCNPN})$ and the sum of individual core strategies (CNSC)

e) Evaluate the linkages between intercompany (AD) and the integrated goals of the supply chain group (IPN)

f) Resulting in a complete and categorised architecture containing principles and areas (ADNPNCN)

This design derived with a set of structures of the individual companies' relevant 


\section{Petar Radanliev}

Architectures for Green-Field Supply Chain Integration

Supply Chain Integration Design

areas of integration, in the context of the on designing individual areas and identifying decisions required for a green-field supply linkages with the areas of all supply chain chain architecture. The structures are focusing participants.

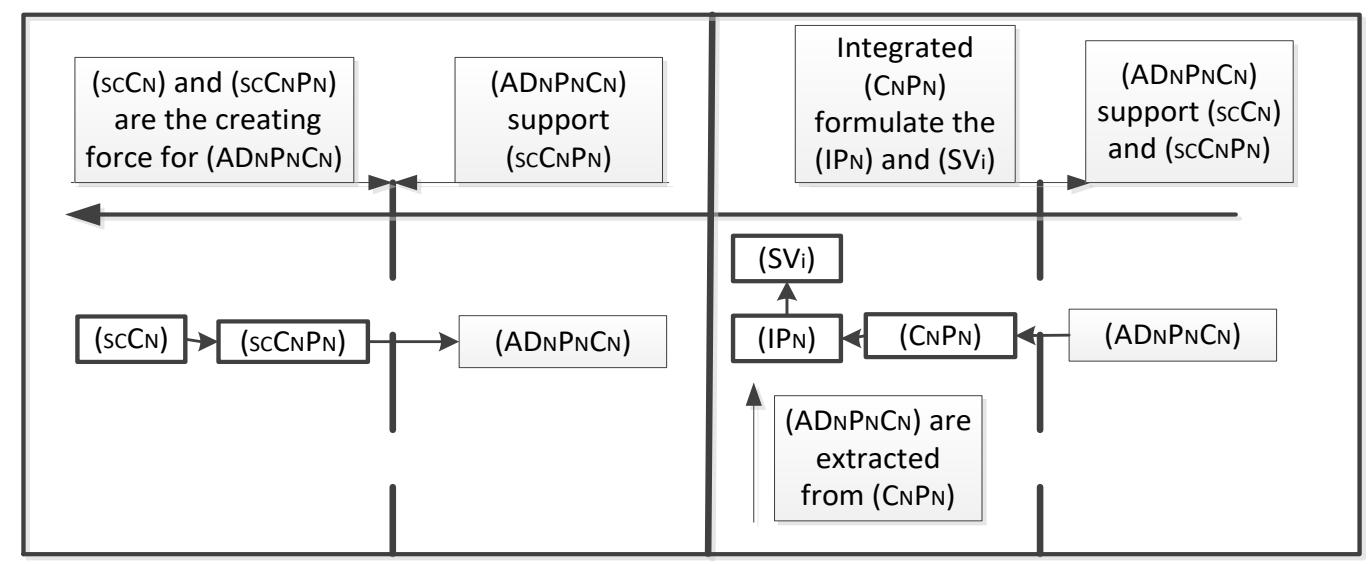

FIGURE 1. CONCEPTUAL APPROACH FOR GREEN-FIELD ARCHITECTURE

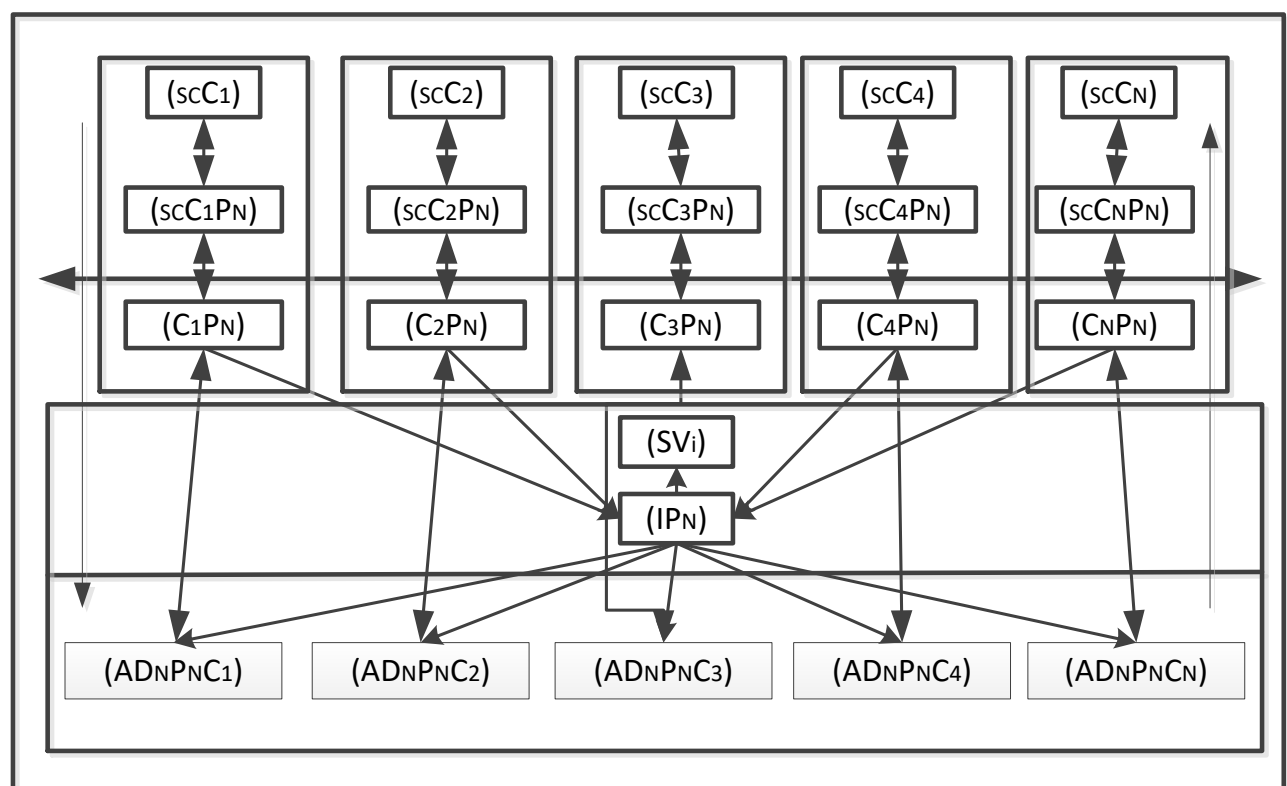

FIGURE 2. THE CORRELATION BETWEEN (CNSC) AND (CN.PN) WITH (ISV) AND (IPN)AND THE (AD) THAT RELATE THE (SCCN) ARCHITECTURE WITH THE (SCCNPN) ARCHITECTURE

The design starts with reviewing the main areas to investigate the elements specific to green-field architecture. Designing the $(\mathrm{ADNPNCN})$ is relatively easy. However, assembling the elements is somewhat of daunting task, because it involves identifying and targeting the strategic tasks to fit the needs of the (CNSC) in a supply chain architecture that:

i. Would assist in achieving the $(\mathrm{ADNPNCN})$ stated in their $(\mathrm{CNSC})$ : 


\section{Petar Radanliev \\ Architectures for Green-Field Supply Chain Integration \\ Supply Chain Integration Design}

ii. Would assist in achieving the

$(\mathrm{ADNPNCN})$ stated in the (ISV).

While at the same time investigating the relationship between $(\mathrm{ADN})$ and the (ADNPNCN) and:

iii. Resulting in a set of architectures containing (AD), which would lead to achieving the (IPN), stated in the (ISV) as described in 2 .

In achieving the outlined and extracting the formulation areas, it is firstly described how the main strategic areas of $(\mathrm{CN})$ can be identified and evaluated in relationship to (CN.PN).

\subsection{Representativeness of the Case Study}

The following stage in the design process involved a series of 20 interviews with the participants (categorised into A, B and C group). The interviews have been performed on the mining industry in North Wales and the participants were selected through convenience sampling. To formulate a green-field supply chain, the mining industry (coded as $\mathrm{C}_{1}$ ) was required to integrate with companies from four related industries. The mining industry needed a retailer for virtual quarries (coded as $\mathrm{C}_{2}$ ), civil engineering company (coded as $\mathrm{C}_{3}$ ), logistic company (coded as $\mathrm{C} 4$ ), and a distribution centre (coded as C5).

The diversity of the population, represented in the supply chain participants, is analysed with reference to the 'Industry Classification Benchmark' to determine the industry representativeness. If the diversity displayed in the sample data findings was established as segmented into company or industry boundaries, the sample data could have been considered as being heavily influenced. In that case, further sampling could have been required to further develop the strategy formulation method. However, the industry diversity displayed in the 'Industry Classification Benchmark' confirmed that the aggregated sample data does not belong to a company or industry. This eliminated the industry dominating factor of company biasing from the formulation methods.

The pool of people interviewed were proportionally representative of the directorial level, managing level, and the operational level supervisors of the supply chain consortium. Only part of the interviews were predetermined in the initial selection and the rest were chosen based on the development of the case study research, this process corresponds with existing literature (Patton, 2002). The interviews were focused on triangulating data collection methods (space, time and people). The same questions were asked in 3 different formats to ensure consistency in the data collected and the extracted passages are recorded as narratives.

\section{CATEGORISING GREEN-FIELD SUPPLY CHAIN CONCEPTS}

To narrow the actual problem, the second question of these sequences was aimed at investigating further the activities of the principles. The design process, indicated that inductive reasoning must be applied to extract and gradually build the supply chain objectives. The design is detailed further in the text through sample passages to present the method.

At this stage, the supply chain design decomposition process recommends grouping objectives and concepts into hierarchical categories started as shown in.

The results are demonstrated in categories and subcategories. The categories created are based on 4 steps: idea, focus, command, and activity.

\subsection{Architecture Methodology}

The architecture methodology is preliminarily applied to the first company $(\mathrm{C} 1)$ whose supply chain is focused on three key 


\section{Petar Radanliev}

Architectures for Green-Field Supply Chain Integration

Supply Chain Integration Design

elements: strict quality control: identify a longer term customer in need of the product, and: work with the longer term customers to develop a strong relationship with the customers. The process of translating ideas into a conceptual diagram is expressed in Fig. 4.

Content analysis and narrative enquiry was applied to advance the diagram. The data analysis from interviews in $\left(\mathrm{C}_{1}\right)$, is illustrated in a supply and demand expanded conceptual diagram Fig. 5.

The same process as in Fig. 4 and Fig. 5 has been applied on all activities and functions to assess the potential for developing the architecture. The ideas on the top are of higher importance in the strategy than these on the bottom that are more tactical ideas, this has been described as 'cascading strategy' (Narasimhan et al., 2008). The hierarchical cascade of the 'cascading strategy' (Narasimhan et al., 2008) enables joining smaller conceptual diagrams to be expanded in the larger conceptual diagram. The 'cascading strategy' was applied to develop further the conceptual diagrams into larger concepts.

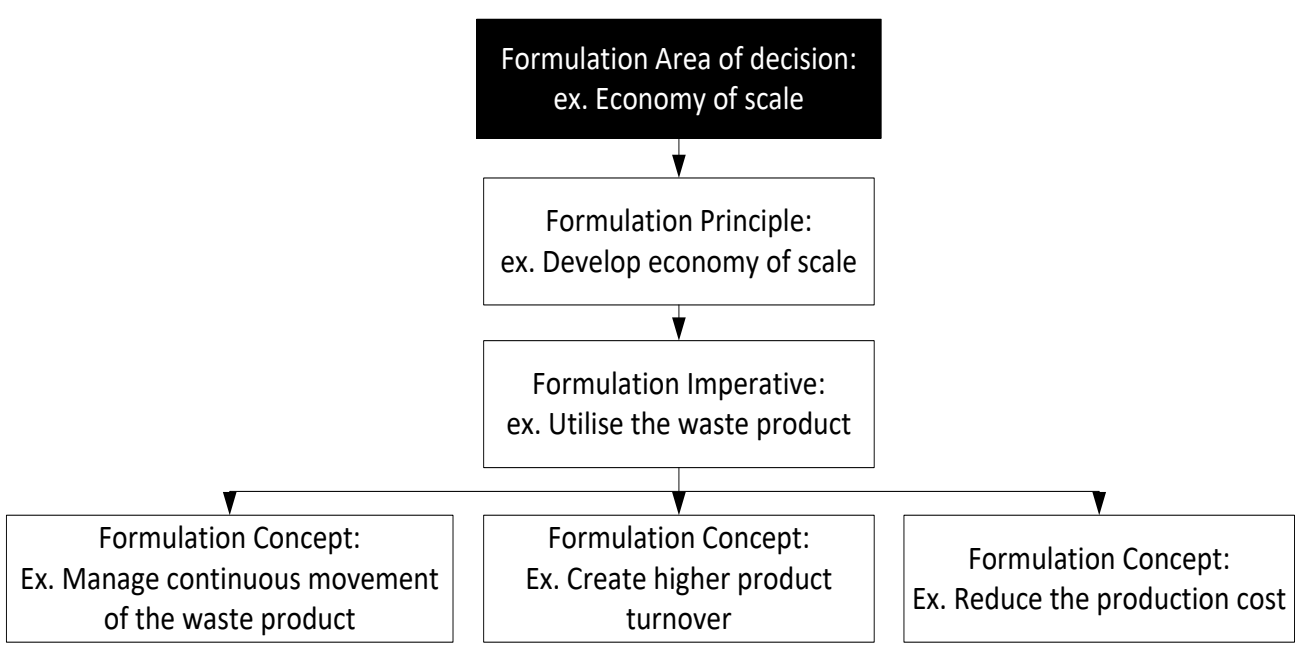

FIGURE 3. CONCEPT CATEGORIES FOR GREEN_FIELD SUPPLY CHAIN ARCHITECTURE 
Petar Radanliev

Architectures for Green-Field Supply Chain Integration

Supply Chain Integration Design

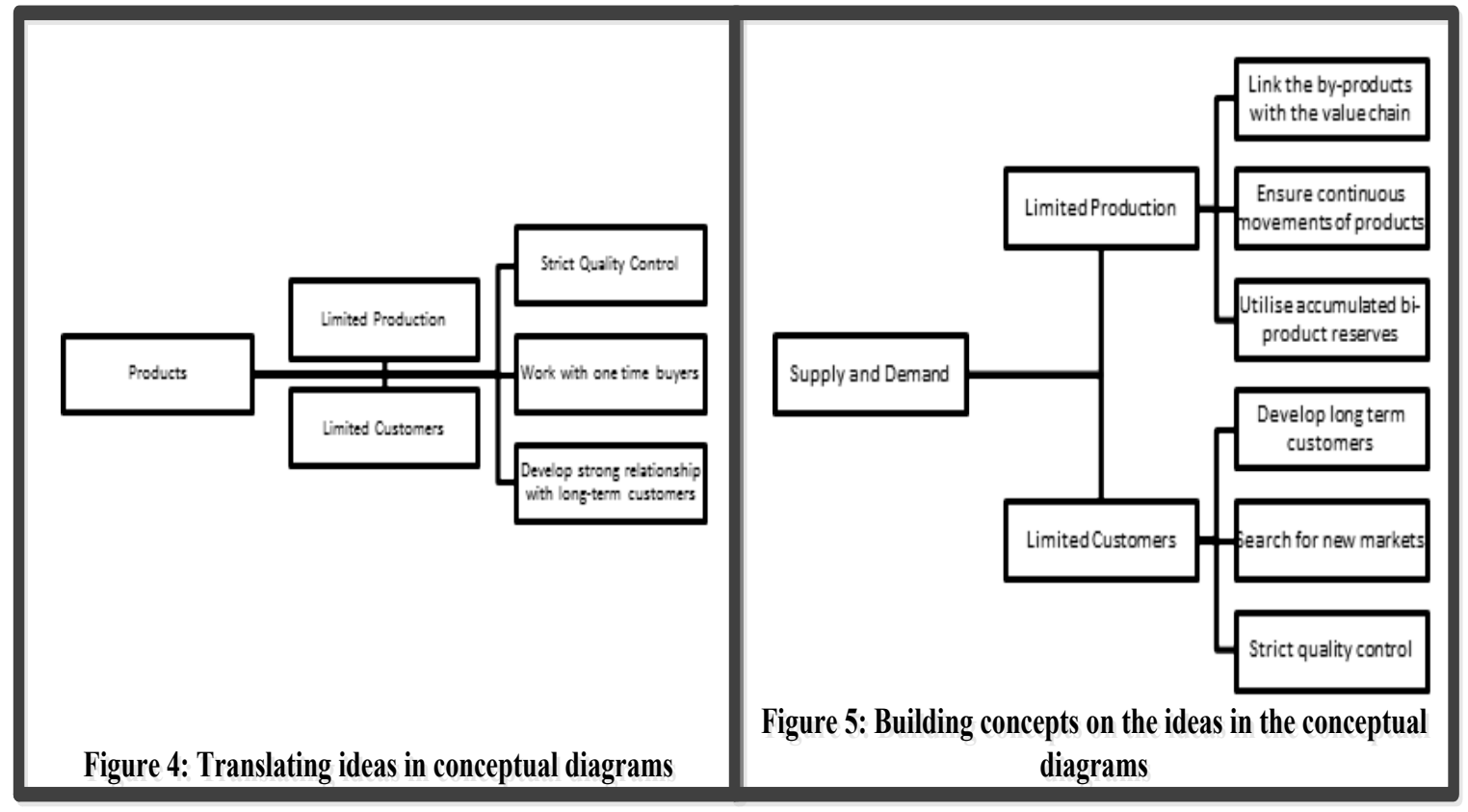

FIGURE 3 AND 5. TRANSLATING AND BUILDING CONCEPTS

\subsection{Strategy Formulation (C1)}

The process starts with the strategic areas of $\left(\mathrm{C}_{1}\right)$. The analysis is based on extracting the idea behind the statements. The process applied open and categorical coding and includes the quotations to illustrate the process. The $\left(\mathrm{C}_{1} \mathrm{P} 1\right)$ presented a few ideas in a single statement and can only be described as superficial statement. To extract the idea behind the superficial statement from the $\left(\mathrm{C}_{1} \mathrm{P} 1\right)$, a number of (AD) were extracted and categorically coded. The following example from $\left(\mathrm{C}_{1} \mathrm{P}_{2}\right)$ was extracted as an area of decision and coded as (AD5C1).

The data analysis process continued until all concepts were identified, examples of the process are outlined. The quotes strengthens the context of $\left(\mathrm{C}_{1} \mathrm{P}_{3}\right)$ and from the text, the $\left(\mathrm{AD}_{1} \mathrm{P}_{3} \mathrm{C}_{1}\right)$ was extracted and confirmed. The quotes also highlighted the value of integration through the visible relationship between $\left(\mathrm{AD}_{1} \mathrm{P}_{3} \mathrm{C}_{1}\right)$ and $\left(\mathrm{AD}_{1} \mathrm{P}_{5} \mathrm{C}_{2}\right), \quad\left(\mathrm{AD}_{1} \mathrm{P}_{6} \mathrm{C}_{2}\right)$,
$\left(\mathrm{AD}_{1} \mathrm{P}_{7} \mathrm{C}_{2}\right)$. Furthermore, the area $\left(\mathrm{AD}_{2} \mathrm{P}_{6} \mathrm{C}_{1}\right)$ was strongly supportive of $\left(\mathrm{C}_{1} \mathrm{P} 6\right)$. Also, from a single quote, a number of areas have been extracted (AD1 $\mathrm{P} 4 \mathrm{C} 1),(\mathrm{AD} 2 \mathrm{P} 4 \mathrm{C} 1),\left(\mathrm{AD} 3 \mathrm{P}_{4} \mathrm{C} 1\right)$ and verified. The quote was also strongly supportive of $\left(\mathrm{C}_{1} \mathrm{P} 4\right)$, and multiple areas present in $(\mathrm{ADNPNCN})$ The outlined process was applied to $\left(\mathrm{C}_{1} \mathrm{PN}\right)$ resulting in the complete list of categorised areas ( $\mathrm{ADNPNC} 1)$. The analysis continued with evaluating if the $\left(\mathrm{ADNPNC}_{1}\right)$ are supportive of individual strategic goals $(\mathrm{SCC} 1 \mathrm{PN})$ and core strategies - (C1SC). The analysis and evaluation was considered required to identify how the areas of green-field architecture lead or assist in achieving the goals stated in the ( $\left.\mathrm{SCC}_{1}\right)$. The data for the analysis of (C1) was obtained from interviews with employees categorised in different groups $(\mathrm{A}, \mathrm{B}, \mathrm{C})$. The relationship between the greenfield architecture and the objectives of their business strategy were coded as: (C1SC). The strategic pillars are coded as: (C1SCP1): (C1scP2): (C1scP3): (C1scP5) in Table 4. 


\section{Petar Radanliev}

Architectures for Green-Field Supply Chain Integration

Supply Chain Integration Design

TABLE 1. EXAMPLE 1 OF (ADN) EXTRACTION PROCESS FOR (C1)

\begin{tabular}{|c|c|}
\hline $\begin{array}{l}\text { Company one }\left(\mathrm{C}_{1}\right) \text { strategic goal } \\
\left(\mathrm{P}_{1}\right):\left(\mathrm{C}_{1} \mathrm{P}_{1}\right)\end{array}$ & $\begin{array}{l}\text { Areas of decision }(A D 1,2,3,4) \text { for }\left(P_{10 f C}\right) \text { : } \\
(A D N P 1 C 1)\end{array}$ \\
\hline $\begin{array}{l}\left(\mathrm{C}_{1} \mathrm{P}_{1}\right) \text { Diversify the processes and outputs } \\
\text { in the quarry }\end{array}$ & $\begin{array}{l}\left(\mathrm{AD}_{1} \mathrm{P}_{1} \mathrm{C}_{1}\right) \text { Supply chain processes and outputs } \\
\left(\mathrm{AD}_{2} \mathrm{P}_{1} \mathrm{C}_{1}\right) \text { Productivity and profits } \\
\left(\mathrm{AD}_{3} \mathrm{P}_{1} \mathrm{C}_{1}\right) \text { Mining cost } \\
\left(\mathrm{AD}_{4} \mathrm{P}_{1} \mathrm{C}_{1}\right) \text { Efficiency }\end{array}$ \\
\hline
\end{tabular}

TABLE 2. EXAMPLE 2 OF (ADN) EXTRACTION PROCESS FOR (C1)

\begin{tabular}{|l|l|}
$\begin{array}{l}\text { Company one }\left(\mathbf{C}_{1}\right) \text { strategic goal } \\
\left(\mathbf{P}_{2}\right):\left(\mathbf{C}_{1} \mathbf{P}_{2}\right)\end{array}$ & $\begin{array}{l}\text { Areas of decision }\left(\mathrm{ADN}_{\mathbf{N}}\right) \text { for }\left(\mathbf{P}_{20} \mathbf{C}_{1}\right) \text { : } \\
\left(\mathbf{A D N}_{\mathbf{N}} \mathbf{C}_{2}\right)\end{array}$ \\
\hline$\left(\mathrm{C}_{1} \mathrm{P}_{2}\right)$ Develop low cost transport & $\left(\mathrm{AD}_{5} \mathrm{P}_{2} \mathrm{C}_{1}\right)$ Transport cost \\
\hline
\end{tabular}

TABLE 2. SUMMARY MAP OF EXTRACTED(ADN) FOR (C1)

\section{Company one (C1) sum of strategic goal $(\mathrm{Pn})$ : (C1PN)}

$\left(\mathrm{C}_{1} \mathrm{P}_{1}\right)$ Diversify the processes and outputs in the quarry

$\left(\mathrm{C}_{1} \mathrm{P}_{2}\right)$ Develop low cost transport $\left(\mathrm{C}_{1} \mathrm{P}_{3}\right)$ Pursue environmental sustainability

$\left(\mathrm{C}_{1} \mathrm{P} 4\right)$ Develop technology, capability and infrastructure

$\left(\mathrm{C}_{1} \mathrm{P}_{5}\right)$ Increase the market share and secure long term market

(C1P6) Build strong brand for the by-product
Sum of areas of decision (ADN) of the first company (C1) : (ADNPNC1)

$\left(\mathrm{AD}_{1} \mathrm{P}_{1} \mathrm{C}_{1}\right)$ Supply chain processes and outputs $\left(\mathrm{AD}_{2} \mathrm{P}_{1} \mathrm{C}_{1}\right)$ Productivity and profits (AD3 $\mathrm{P}_{1} \mathrm{C}_{1}$ ) Mining cost $\left(\mathrm{AD} 4 \mathrm{P}_{1} \mathrm{C}_{1}\right)$ Efficiency (AD1 $\left.\mathrm{P}_{2} \mathrm{C}_{1}\right)$ Transport cost $\left(\mathrm{AD}_{1} \mathrm{P}_{3} \mathrm{C}_{1}\right)$ Impact on environment (AD1 $\mathrm{P}_{4} \mathrm{C}_{1}$ ) Supply chain technology $\left(\mathrm{AD}_{2} \mathrm{P}_{4} \mathrm{C}_{1}\right)$ Supply chain capability (AD3 $\mathrm{P}_{4} \mathrm{C}_{1}$ ) Supply chain infrastructure

$\left(\mathrm{AD}_{1} \mathrm{P}_{5} \mathrm{C}_{1}\right)$ Supply chain market

$\left(\mathrm{AD}_{2} \mathrm{P}_{6} \mathrm{C}_{1}\right)$ Supply chain brand

TABLE 3. SUMMARY MAP OF EXTRACTED (SCC1PN) FOR (C1)

\begin{tabular}{|c|c|c|}
\hline $\begin{array}{l}\text { Strategic Core } \\
\text { (SC) of }\left(\mathrm{C}_{1}\right) \text { : }\end{array}$ & \multicolumn{2}{|c|}{ Strategic pillars $\left(\mathrm{PN}_{\mathrm{N}}\right)$ from $\left(\mathrm{SCC}_{1}\right)$ : ( $\left.\mathrm{SCC}_{1} \mathrm{PN}_{\mathrm{N}}\right)$} \\
\hline \multirow{4}{*}{$\left(\mathrm{SCC}_{1}\right)$} & $\left(\mathrm{C}_{1} \mathrm{SCP}_{1}\right),\left(\mathrm{C}_{1} \mathrm{SCP}_{2}\right)$ & \multirow{4}{*}{$\begin{array}{l}\text { Extraction and validation of } \\
\left(\mathrm{SCC} \mathrm{P}_{\mathrm{P}}\right) \text { and confirmation of } \\
\text { linkages with (ADNPNC1): } \\
\text { Primary data }\end{array}$} \\
\hline & $\left(\mathrm{C}_{1} \mathrm{SCP}_{3}\right)$ & \\
\hline & $\left(\mathrm{C}_{1} \mathrm{SCP} 4\right)$ & \\
\hline & $\left(\mathrm{C}_{1} \mathrm{SCP}_{5}\right)$ & \\
\hline
\end{tabular}


Petar Radanliev

Architectures for Green-Field Supply Chain Integration

Supply Chain Integration Design

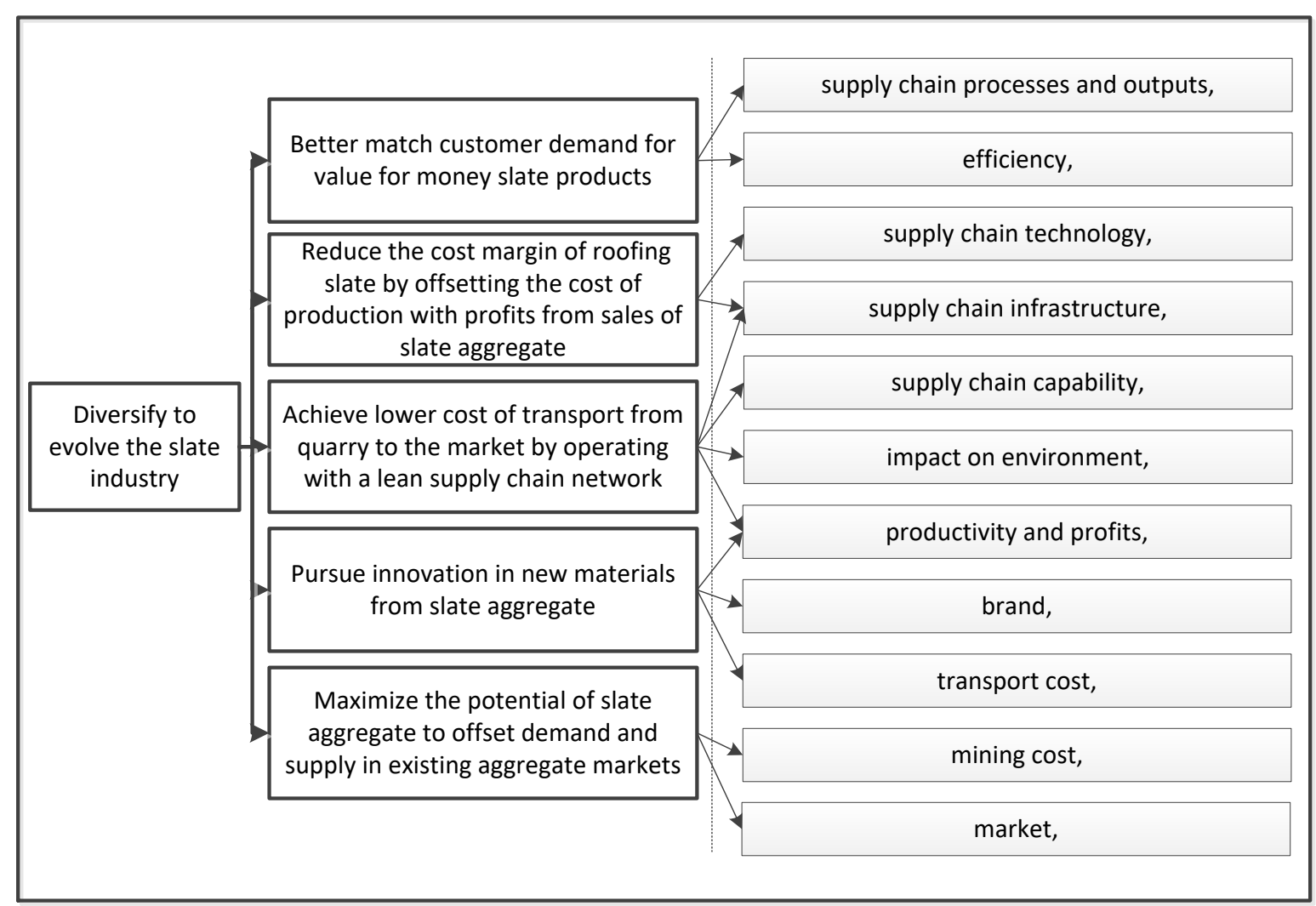

FIGURE 6. RELATIONSHIP BETWEEN ( $\left.\mathrm{sCC}_{1} \mathrm{P}_{\mathrm{N}}\right) \operatorname{AND}(\mathrm{ADN}) \mathrm{FOR}\left(\mathrm{C}_{1}\right)$

This design resulted in a set of constructions that can be used as a tool to extract an abstract of individual companies' tacit operational integration leakages relevant in the context of supply chain architecture. The set of constructions enables evaluating if there are sufficient linkages between: the abstract individual areas (AD), the green-field principles (IPN) and the existing individual strategic goals $(\mathrm{SCCNPN})$. This phase is crucial for ensuring the green-field architecture leads or assists in achieving the goals stated in the $(\mathrm{SCCNPN})$ and individual $(\mathrm{CNSC})$. Therefore, evaluating the linkages must come prior relating the as elements to the supply chain architecture (Fig. 7).

\section{FORMULATION PRINCIPLES}

The design process discovered that some of the areas could not be joined but they were far too closely related to be separate areas.
This is the reasoning behind the additional category, coded as principles $\left(\mathrm{FP}_{\mathrm{N}}\right)$. The $\left(\mathrm{FP}_{\mathrm{N}}\right)$ allowed maintaining a manageable number of $\left(A D_{N}\right)$. The experience from the field-work advocates a recommended level of no more than $10\left(\mathrm{AD}_{\mathrm{N}}\right)$ and no more than $20\left(\mathrm{FP}_{\mathrm{N}}\right)$. In the cases where these numbers are exceeded the researcher should review the data sets and take sensitive action to keep the $\left(\mathrm{AD}_{\mathrm{N}}\right)$ and $\left(\mathrm{FP}_{\mathrm{N}}\right)$ within the recommended range. This helps in recording all the data in a simplified illustration. For example, the field work with $\left(\mathrm{C}_{1}\right)$, resulted with this number exceeding well beyond the limits recommended. The same process mentioned with $\left(\mathrm{C}_{3}\right)$ was applied on linking only the salient areas. To simplify the process $\left(\mathrm{FP}_{\mathrm{N}}\right)$ were used after the salient areas, where the $\left(\mathrm{FP}_{\mathrm{N}}\right)$ acted in a way as sub-salient-areas. The sub-salient-areas were grouped with three activities. The grouping involved clustering the activities in clusters of three and naming the clusters. 


\section{Petar Radanliev}

Architectures for Green-Field Supply Chain Integration

Supply Chain Integration Design

The third pattern was that strategic goals can have closely associated principle action objectives. For example the action objective 'reduce cost' presents a closely associated action objective as 'reduce asset cost' (Fig. 8). These action objectives are structured hierarchically into the (AD) to group related action objectives. However, a different emerging pattern is that some of the action objectives ex. 'reduce cost' required multiple strategic decisions, while 'reduce asset cost' required strategic decisions solely focused on a specific cost. This caused the data analysis to seek additional patterns that can be placed in concept categories. The recorded formulation principles as extracted are interrelated in the sense that the aim is achieving certain objectives. The wording was studied further to create links between the aim and objectives. Some objectives were aimed at achieving status such as 'be effective in the market', while other statements are aimed at achieving actions such as 'increase sales'. From the data analysis it also became obvious that regardless of the objective being focused on action or status they were explicitly present as concepts that require decisions. The difference in the action objectives was analysed and represented in different categories (Fig. 9).

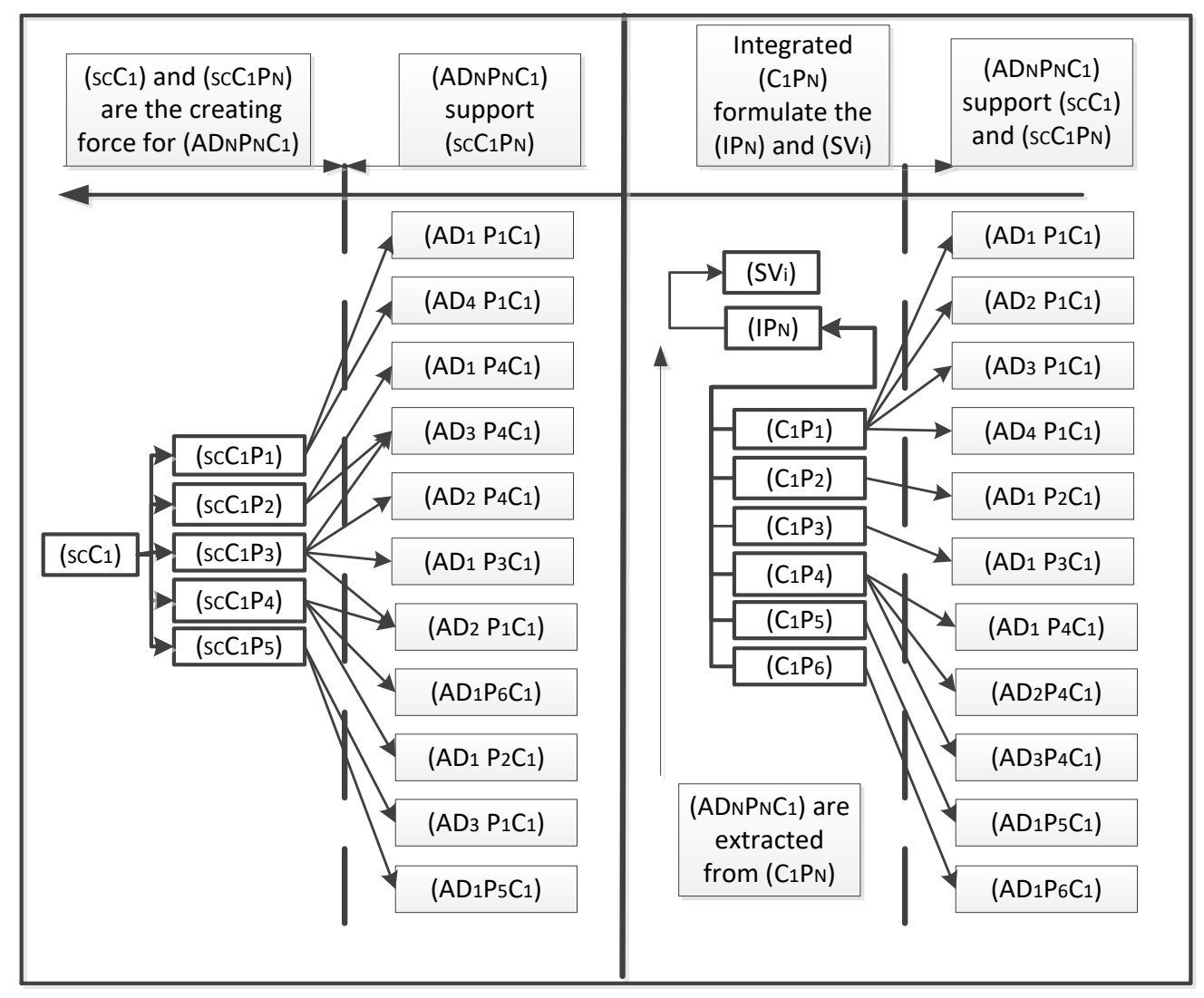

FIGURE 7. CONCEPTUAL ARCHITETURE OF THE CORRELATION BETWEEN THE (PN) AND (SCCNPN), (ISV) AND (IPN) AND (AD $)$

\begin{tabular}{c}
$\begin{array}{c}\text { Conceptual } \\
\text { Method }\end{array}$ \\
Vision \\
\hline Goals \\
\hline Pursue profitable markets \\
(C1PN)
\end{tabular}




\section{Petar Radanliev}

Architectures for Green-Field Supply Chain Integration

Supply Chain Integration Design

FIGURE 8. FRAMEWORK BUILDING - RELATING EMERGING CONCEPTS TO THE CATEGORIES 


\section{Petar Radanliev}

Architectures for Green-Field Supply Chain Integration

Supply Chain Integration Design

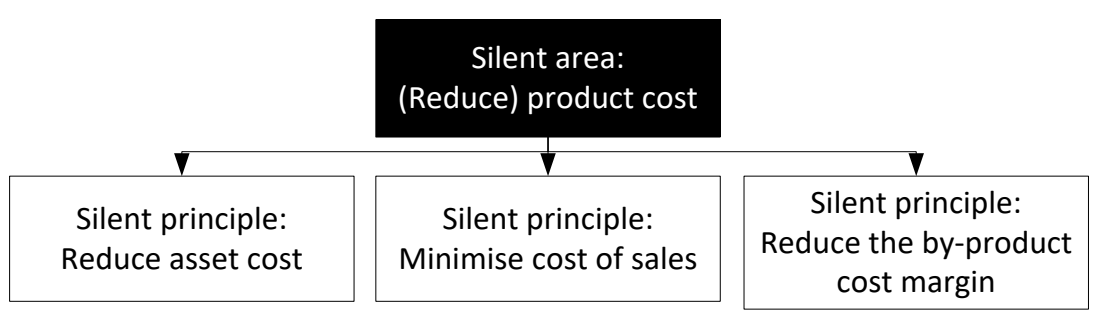

FIGURE 9. ARCHITECTING THE DESIGN FROM THE SALIENT AREAS

\subsection{Extracting the Formulation Principles}

The emerging design process applied design decomposition to progressively build the action objectives (Fig. 10). The extracted action objectives and concepts have been assembled to the $\left(\mathrm{C}_{1} \mathrm{PN}\right)$. By assembling the action objectives into categories, patterns started to emerge. The first pattern was that action objectives can be interconnected. The second emerging pattern was that concepts that cannot be classified as principles started to emerge. For example outsourcing non-core operations was not a principle decision for integration and formulation. The action objective represented an imperative objective that need to be addressed with the supply chain participants.

\subsection{Formulation of Supply Chain Tasks and Activities}

The focus was placed on the new emerging categories. The categories in represented the areas of decision and principle actions required for the supply chain to operate. The process of identifying the final two categories has benefited to a great extent in terms of narrowing the researched goals by categorising the emerging categories into areas and principles.

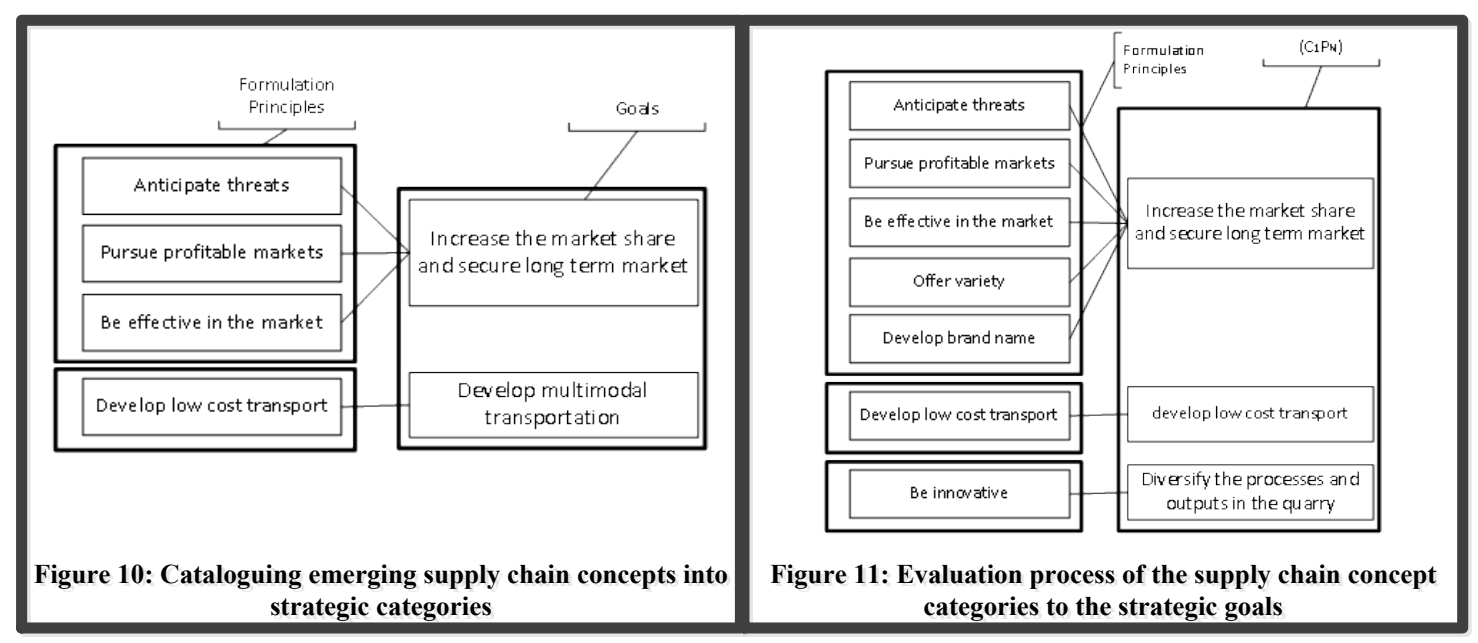

FIGURES 10 AND 11. CATALOGUING AND EVALUATING CONCEPTS 
Petar Radanliev

Architectures for Green-Field Supply Chain Integration

Supply Chain Integration Design

TABLE 4. CONCEPTUAL SUMMARY MAP OF SALIENT AREAS AND PRINCIPLES

\begin{tabular}{|c|c|}
\hline$\left(\mathrm{ADNC}_{1}\right)$ & $\left(\mathrm{FPNC}_{1}\right)$ \\
\hline$\left(\mathrm{AD}_{1} \mathrm{P}_{1} \mathrm{C}_{1}\right)$ Supply chain processes & $\left(\mathrm{AD}_{1} \mathrm{P}_{1 \mathrm{FP}} \mathrm{C}_{1}\right)$ Diversify logistics chain processes \\
\hline$\left(\mathrm{AD}_{2} \mathrm{P}_{1} \mathrm{C}_{1}\right)$ Productivity and profits & $\begin{array}{l}\left(\mathrm{AD}_{2} \mathrm{P}_{1} \mathrm{FP}_{1} \mathrm{C}_{1}\right) \text { Increase our productivity and } \\
\text { profits }\end{array}$ \\
\hline$\left(\mathrm{AD}_{3} \mathrm{P}_{1} \mathrm{C}_{1}\right)$ Mining cost & $\left(\mathrm{AD}_{3} \mathrm{P}_{1} \mathrm{FP}_{1} \mathrm{C}_{1}\right)$ Reduce the cost of mining \\
\hline$\left(\mathrm{AD} 4 \mathrm{P}_{1} \mathrm{C}_{1}\right)$ Supply chain efficiency & $\left(\mathrm{AD} 4 \mathrm{P}_{1 \mathrm{FP} 1 \mathrm{C}}\right)_{1}$ increase the supply chain efficiency \\
\hline$\left(\mathrm{AD}_{1} \mathrm{P}_{2} \mathrm{C}_{1}\right)$ Transport cost & $\begin{array}{l}\left(\mathrm{AD}_{1} \mathrm{P}_{2} \mathrm{FP}_{1} \mathrm{C}_{1}\right) \text { Minimise transportation cost } \\
\left(\mathrm{AD}_{1} \mathrm{P}_{2 \mathrm{FP} 2} \mathrm{C}_{1}\right) \text { Develop sustainable transport }\end{array}$ \\
\hline$\left(\mathrm{AD}_{1} \mathrm{P}_{3} \mathrm{C}_{1}\right)$ Impact on environment & $\begin{array}{l}\text { (AD1P3FP1C1) Pursue environmental } \\
\text { sustainability }\end{array}$ \\
\hline$\left(\mathrm{AD}_{1} \mathrm{P}_{4} \mathrm{C}_{1}\right)$ Supply chain technology & $\left(\mathrm{AD} 1 \mathrm{P}_{4} \mathrm{FP} 1 \mathrm{C}_{1}\right)$ Acquire new technology \\
\hline$\left(\mathrm{AD}_{2} \mathrm{P}_{4} \mathrm{C}_{1}\right)$ Supply chain capability & $\left(\mathrm{AD}_{2} \mathrm{P}_{4 \mathrm{FP}} \mathrm{C}_{1}\right)$ Invest in supply chain capabilities \\
\hline ( $\left.\mathrm{AD}_{3} \mathrm{P}_{4} \mathrm{C}_{1}\right)$ Supply chain infrastructure & $\begin{array}{l}\text { (AD3P4FP1C1) Maximise usage of existing supply } \\
\text { chain infrastructure }\end{array}$ \\
\hline$\left(\mathrm{AD}_{1} \mathrm{P}_{5} \mathrm{C}_{1}\right)$ Supply chain market & $\begin{array}{l}\left(\mathrm{AD}_{1} \mathrm{P}_{5 \mathrm{FP}} \mathrm{C}_{1}\right) \text { Be effective in the market } \\
\left(\mathrm{AD}_{1} \mathrm{P}_{5 \mathrm{~F}} \mathrm{C}_{2}\right) \text { Increase sale volumes }\end{array}$ \\
\hline$\left(\mathrm{AD}_{1} \mathrm{~S}_{1} \mathrm{C}_{1}\right)$ Supply chain brand & $\left(\mathrm{AD}_{1} \mathrm{~S}_{1 \mathrm{FP}} \mathrm{C}_{1}\right)$ Develop new supply chain brand \\
\hline$\left(\mathrm{AD}_{1} \mathrm{~S}_{2} \mathrm{C}_{1}\right)$ Economy of scale & $\left(\mathrm{AD}_{1} \mathrm{~S}_{2 \mathrm{FP}} \mathrm{C}_{1}\right)$ Develop economy of scale \\
\hline$\left(\mathrm{AD}_{1} \mathrm{~S}_{3} \mathrm{C}_{1}\right)$ Demand planning & $\left(\mathrm{AD}_{1} \mathrm{~S}_{3 \mathrm{FP}} \mathrm{C}_{1}\right)$ Plan by-product demand \\
\hline$\left(\mathrm{AD}_{1} \mathrm{~S}_{4} \mathrm{C}_{1}\right)$ Production costs & $\begin{array}{l}\left(\mathrm{AD}_{1} \mathrm{~S}_{4 \mathrm{FP}} \mathrm{C}_{1}\right) \text { Minimise cost of sales } \\
\left(\mathrm{AD} 1 \mathrm{~S}_{4 \mathrm{FP}} \mathrm{C}_{1}\right) \text { Reduce the by-product cost margin } \\
\left(\mathrm{AD} 1 \mathrm{~S}_{4 \mathrm{FP}} \mathrm{C}_{1}\right) \text { Reduce asset cost }\end{array}$ \\
\hline$\left(\mathrm{AD}_{1} \mathrm{~S}_{5} \mathrm{C}_{1}\right)$ Supply chain potential & $\begin{array}{l}\text { (AD1S5FP1C1) Maximise the potential supply and } \\
\text { usage of the by-product }\end{array}$ \\
\hline$\left(\mathrm{AD}_{1} \mathrm{~S}_{6} \mathrm{C}_{1}\right)$ Supply chain volume & $\left(\mathrm{AD}_{1} \mathrm{~S}_{\left.6 \mathrm{FP} 1 \mathrm{C}_{1}\right)}\right.$ Increase sale volumes \\
\hline $\begin{array}{l}\left(\mathrm{AD} 1 \mathrm{~S}_{7} \mathrm{C}_{1}\right) \text { Education and } \\
\text { development }\end{array}$ & $\left(\mathrm{AD}_{1} \mathrm{~S}_{\left.7 \mathrm{FP}_{1} \mathrm{C}_{1}\right) \text { Educate and develop }}\right.$ \\
\hline$\left(\mathrm{AD}_{1} \mathrm{~S}_{8} \mathrm{C}_{1}\right)$ Supply chain innovation & $\left(\mathrm{AD}_{1} \mathrm{~S}_{\left.8 \mathrm{FP} 1 \mathrm{C}_{1}\right)}\right)_{\text {Innovation in new materials }}$ \\
\hline
\end{tabular}

\subsection{Catalogue Salient Activities in Salient Dimensions}

The process of confirming validity was targeted at observing sufficient evidence and if that was not available in a certain area of activity, the activities were disregarded. The design process is divided into five steps:

1. Investigate the salient areas

2. Identifying salient categories of activity in the salient dimensions

3. Investigate the activities in each category

4. Investigate the support factors for each activity
5. Double-check for sufficient amount of evidence of supporting concepts

6. Summarise the activities into hierarchy

The first step was focused on identifying recording and coding in imperative statements the salient activities.

The first task after identifying the salient areas was to investigate the activities in each area. The method suggested in this study represents looking at the concrete examples of activities to prove the validity of any salient areas with a recorded formulation imperatives $\left(\mathrm{FC}_{\mathrm{N}} \mathrm{FI}_{\mathrm{N}} \mathrm{C}_{\mathrm{N}}\right)$. 


\section{Petar Radanliev}

Architectures for Green-Field Supply Chain Integration

Supply Chain Integration Design

TABLE 5. PROGRESSIVELY BUILDING IMPERATIVE CONCEPTS - (FIN) TO VALIDATE THE PRINCIPLE CATEGORIES

\section{Formulation Imperatives $\left(\mathrm{FI}_{\mathrm{N}}\right)$}

$\left(\mathrm{FI}_{1} \mathrm{C}_{1}\right)$ Make the supply chain from quarry to customer more cost efficient $\left(\mathrm{FI}_{2} \mathrm{C}_{1}\right)$ Become as efficient as other quarries

$\left(\mathrm{FI}_{3} \mathrm{C}_{1}\right)$ Make the slate aggregate by-product affordable for distant customers

TABLE 6. PROGRESSIVELY BUILDING THE CONCEPTUAL TASKS - TO VALIDATE THE IMPERATIVE CONVEPTS - $\left(\mathrm{FC}_{\mathrm{N}} \mathrm{C}_{3}\right)$

\begin{tabular}{|c|c|}
\hline$\left(\mathrm{FI}_{\mathrm{N}} \mathrm{C}_{3}\right)$ & $\left(\mathrm{FC}_{\mathrm{N}} \mathrm{C}_{3}\right)$ \\
\hline$\left(\mathrm{FI}_{1} \mathrm{C}_{3}\right)$ & $\left(\mathrm{FC}_{1} \mathrm{FI}_{1} \mathrm{C}_{3}\right),\left(\mathrm{FC}_{2} \mathrm{FI}_{1} \mathrm{C}_{3}\right)$ \\
\hline
\end{tabular}

TABLE 7. CONVEPTUAL SUMMARY MAP RESULTING FROM PROGRESSIVELY RELATING INDIVIDUAL FUNCTIONAL PRINCIPLES - (FPNC1) WITH INDIVIDUAL FUNCTIONAL IMPERATIVES- (FINC1)

\begin{tabular}{|c|c|}
\hline$\left(\mathrm{FPnC}_{1}\right)$ & $\left(\mathrm{FInC}_{1}\right)$ \\
\hline $\begin{array}{c}\left(\mathrm{AD} 1 \mathrm{P}_{1} \mathrm{~F}_{1} \mathrm{C}_{1}\right) \text { Example: Diversify } \\
\text { our logistics chain processes and } \\
\text { outputs }\end{array}$ & $\begin{array}{c}(\mathrm{AD} 1 \mathrm{P} 1 \mathrm{~F} 1 \mathrm{~F} 1 \mathrm{C} 1) \\
\text { Example: Pursue supply chain } \\
\text { integration }\end{array}$ \\
\hline$\left(\mathrm{AD}_{2} \mathrm{P}_{1 F P} \mathrm{C}_{1}\right)$ & $\left(\mathrm{AD}_{2} \mathrm{P}_{1 \mathrm{FP}} 1 \mathrm{FI} 1 \mathrm{C}_{1}\right)$ \\
\hline$\left(\mathrm{AD}_{3} \mathrm{P}_{1 \mathrm{FP}} \mathrm{C}_{1}\right)$ & $\left(\mathrm{AD}_{3} \mathrm{P}_{1 \mathrm{FP}} \mathrm{FI}_{1} \mathrm{C}_{1}\right)$ \\
\hline$\left(\mathrm{AD} 4 \mathrm{P}_{\left.1 \mathrm{FP} 1 \mathrm{C}_{1}\right)}\right.$ & $\left(\mathrm{AD}_{4} \mathrm{P}_{1 \mathrm{FP}} \mathrm{FI}_{1} \mathrm{C}_{1}\right)$ \\
\hline$\left(\mathrm{AD}_{1} \mathrm{P}_{2} \mathrm{FP}_{1} \mathrm{C}_{1}\right)$ & $\left(\mathrm{AD}_{1} \mathrm{P}_{2} \mathrm{FP} 1 \mathrm{FI} 1 \mathrm{C}_{1}\right)$ \\
\hline$\left(\mathrm{AD}_{1} \mathrm{P}_{2} \mathrm{FP}_{2} \mathrm{C}_{1}\right)$ & $\left(\mathrm{AD}_{1} \mathrm{P}_{2 \mathrm{FP}} \mathrm{FI}_{1} \mathrm{C}_{1}\right)$ \\
\hline$\left(\mathrm{AD}_{1} \mathrm{P}_{3} \mathrm{FP}_{1} \mathrm{C}_{1}\right)$ & $\left(\mathrm{AD}_{1} \mathrm{P}_{3} \mathrm{FP} 1 \mathrm{FI} 1 \mathrm{C}_{1}\right)$ \\
\hline$\left(\mathrm{AD}_{1} \mathrm{P}_{4 \mathrm{FP}} \mathrm{C}_{1}\right)$ & $(\mathrm{AD} 1 \mathrm{P} 4 \mathrm{FP} 1 \mathrm{FI} 1 \mathrm{C} 1)$ \\
\hline$\left(\mathrm{AD}_{2} \mathrm{P}_{4 \mathrm{FP}} \mathrm{C}_{1}\right)$ & $\left(\mathrm{AD}_{2} \mathrm{P}_{4} \mathrm{FP} 1 \mathrm{FP} 1 \mathrm{C}_{1}\right)$ \\
\hline$\left(\mathrm{AD}_{3} \mathrm{P}_{4} \mathrm{FP} 1 \mathrm{C}_{1}\right)$ & $\left(\mathrm{AD}_{3} \mathrm{P}_{4 \mathrm{FP}} \mathrm{FI}_{1} \mathrm{C}_{1}\right)$ \\
\hline$\left(\mathrm{AD}_{1} \mathrm{P}_{5 \mathrm{FP}} \mathrm{C}_{1}\right)$ & $\left(\mathrm{AD}_{1} \mathrm{P}_{5 \mathrm{FP}} \mathrm{FI}_{1} \mathrm{C}_{1}\right)$ \\
\hline$\left(\mathrm{AD}_{1} \mathrm{P}_{5 \mathrm{FP}} \mathrm{C}_{1}\right)$ & $\left(\mathrm{AD}_{1} \mathrm{P}_{5 \mathrm{FP}} \mathrm{FI}_{1} \mathrm{C}_{1}\right)$ \\
\hline$\left(\mathrm{AD}_{1} \mathrm{~S}_{\left.1 \mathrm{FP} 1 \mathrm{C}_{1}\right)}\right.$ & $\left(\mathrm{AD}_{1} \mathrm{~S}_{1 F P 1 F I 1} \mathrm{C}_{1}\right)$ \\
\hline$\left(\mathrm{AD}_{1} \mathrm{~S}_{2} \mathrm{FP}_{1} \mathrm{C}_{1}\right)$ & $\left(\mathrm{AD}_{1} \mathrm{~S}_{2} \mathrm{FP} 1 \mathrm{FI} 1 \mathrm{C}_{1}\right)$ \\
\hline$\left(\mathrm{AD}_{1} \mathrm{~S}_{3} \mathrm{FP}_{1} \mathrm{C}_{1}\right)$ & $\begin{array}{l}\left(\mathrm{AD} 1 \mathrm{~S}_{3} \mathrm{FP} 1 \mathrm{FI} 1 \mathrm{C} 1\right) \\
\left(\mathrm{AD} 1 \mathrm{~S}_{3 F P 1 F 12} \mathrm{C}_{1}\right)\end{array}$ \\
\hline$\left(\mathrm{AD} 1 \mathrm{~S}_{4} \mathrm{FP} 1 \mathrm{C}_{1}\right)$ & $\left(\mathrm{AD} 1 \mathrm{~S}_{4} \mathrm{FP} 1 \mathrm{FI} 1 \mathrm{C}_{1}\right)$ \\
\hline$\left(\mathrm{AD}_{1} \mathrm{~S}_{4 \mathrm{FP}} \mathrm{C}_{1}\right)$ & $\left(\mathrm{AD} 1 \mathrm{~S}_{4} \mathrm{FP} 2 \mathrm{FI} 1 \mathrm{C}_{1}\right)$ \\
\hline$\left(\mathrm{AD}_{1} \mathrm{~S}_{4 \mathrm{FP}} \mathrm{C}_{1}\right)$ & $(\mathrm{AD} 1 \mathrm{~S} 4 \mathrm{FP} 3 \mathrm{FI} 1 \mathrm{C} 1)$ \\
\hline$\left(\mathrm{AD}_{1} \mathrm{~S}_{5 \mathrm{FP}} \mathrm{C}_{1}\right)$ & $\left(\mathrm{AD} 1 \mathrm{~S}_{5 \mathrm{FP}} \mathrm{FII}_{1} \mathrm{C}_{1}\right)$ \\
\hline$\left(\mathrm{AD}_{1} \mathrm{~S}_{6 \mathrm{FP}} \mathrm{C}_{1}\right)$ & $\left(\mathrm{AD}_{1} \mathrm{~S}_{6 \mathrm{FP}} \mathrm{FII}_{1} \mathrm{C}_{1}\right)$ \\
\hline$\left(\mathrm{AD}_{1} \mathrm{~S}_{7 \mathrm{FP}} \mathrm{C}_{1}\right)$ & $\left(\mathrm{AD} 1 \mathrm{~S}_{7 F P 1 F I 1} \mathrm{C}_{1}\right)$ \\
\hline$\left(\mathrm{AD} 1 \mathrm{~S}_{8 \mathrm{FP}} \mathrm{C}_{1}\right)$ & $\left(\mathrm{AD} 1 \mathrm{~S}_{8 \mathrm{FP}} \mathrm{FII}_{1} \mathrm{C}_{1}\right)$ \\
\hline
\end{tabular}


Petar Radanliev

Architectures for Green-Field Supply Chain Integration

Supply Chain Integration Design

\section{TABLE 8. PROGRESSIVELY RELATING INDIVIDUAL CONCEPTUAL IMPERATIVES WITH INDIVIDUAL CONCEPTUAL TASKS IN THE FORM OF ACTIVITIES}

\begin{tabular}{|c|c|}
\hline$(\mathrm{FInC} 1)$ & $\left.\mathrm{InC}_{1}\right)$ \\
\hline $\begin{array}{l}(\mathrm{AD} 1 \mathrm{P} 1 \mathrm{FP} 1 \mathrm{~F} 1 \mathrm{C} 1) \\
\text { Example: Pursue } \\
\text { supply chain } \\
\text { integration }\end{array}$ & $\begin{array}{l}(\mathrm{AD} 1 \mathrm{P} 1 \mathrm{FP} 1 \mathrm{~F} 1 \mathrm{~A} 1 \mathrm{C} 1) \\
\text { Example: Integrate with } 3 P \text { Ls that can operate on Conwy Valley Line } \\
\left(\mathrm{AD} 1 \mathrm{P}_{1 \mathrm{FP}} \mathrm{F}_{1} \mathrm{~A} 2 \mathrm{C} 1\right) \\
\text { Example: Pursue supply chain integration that would enable } \\
\text { multimodal transport } \\
\text { (AD1P1FP1FI1 } \mathrm{A} 3 \mathrm{C} 1) \\
\text { Example: Pursue sea transport through Port of Mostyn }\end{array}$ \\
\hline$\left(\mathrm{AD}_{2} \mathrm{P}_{1 \mathrm{FP}} 1 \mathrm{FI} 1 \mathrm{C}_{1}\right)$ & $\left(\mathrm{AD}_{2} \mathrm{P} 1 \mathrm{FP} 1 \mathrm{FI} 1 \mathrm{~A} 1 \mathrm{C} 1\right),\left(\mathrm{AD}_{2} \mathrm{P} 1 \mathrm{FP} 1 \mathrm{FI} 1 \mathrm{~A} 2 \mathrm{C} 1\right),\left(\mathrm{AD}_{2} \mathrm{P} 1 \mathrm{FP} 1 \mathrm{FI} 1 \mathrm{~A} 3 \mathrm{C}_{1}\right)$ \\
\hline$\left(\mathrm{AD}_{3} \mathrm{P}_{1 F P 1 F 11} \mathrm{C}_{1}\right)$ & $\left(\mathrm{AD}_{3} \mathrm{P}_{1 F P} \mathrm{~F}_{\mathrm{F}} 1 \mathrm{~A} 1 \mathrm{C} 1\right),\left(\mathrm{AD}_{3} \mathrm{P}_{1 F P} \mathrm{~F}_{\mathrm{F}} 1 \mathrm{~A} 2 \mathrm{C}_{1}\right)$ \\
\hline$\left(\mathrm{AD} 4 \mathrm{P}_{1 F P 1 F 11} \mathrm{C}_{1}\right)$ & $(\mathrm{AD} 4 \mathrm{P} 1 \mathrm{FP} 1 \mathrm{~F} 1 \mathrm{~A} 1 \mathrm{C} 1),\left(\mathrm{AD} 4 \mathrm{P} 1 \mathrm{FP} 1 \mathrm{FI} 1 \mathrm{~A} 2 \mathrm{C}_{1}\right),\left(\mathrm{AD} 4 \mathrm{P} 1 \mathrm{FP} 1 \mathrm{FI} 1 \mathrm{~A} 3 \mathrm{C}_{1}\right)$ \\
\hline$\left(\mathrm{AD}_{1} \mathrm{P}_{2 \mathrm{FP}} \mathrm{F}_{11} \mathrm{C}_{1}\right)$ & 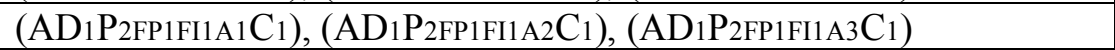 \\
\hline$\left(\mathrm{AD}_{1} \mathrm{P}_{2 \mathrm{FP}} \mathrm{FI} 1 \mathrm{C}_{1}\right)$ & $\left(\mathrm{AD} 1 \mathrm{P}_{2 \mathrm{FP}} \mathrm{F} 11 \mathrm{~A} 1 \mathrm{C}_{1}\right)$ \\
\hline$\left(\mathrm{AD}_{1} \mathrm{P}_{3} \mathrm{FP} 1 \mathrm{FI} 1 \mathrm{C}_{1}\right)$ & 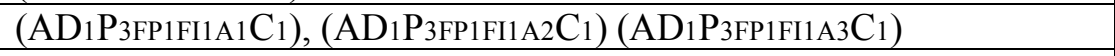 \\
\hline$\left(\mathrm{AD}_{1} \mathrm{P}_{4 \mathrm{FP}} 1 \mathrm{FI} 1 \mathrm{C}_{1}\right)$ & $\left(\mathrm{AD}_{1} \mathrm{P}_{4} \mathrm{FP} 1 \mathrm{FI} 1 \mathrm{~A} 1 \mathrm{C}_{1}\right),\left(\mathrm{AD} 1 \mathrm{P}_{4} \mathrm{FP} 1 \mathrm{FI} 1 \mathrm{~A} 2 \mathrm{C}_{1}\right),\left(\mathrm{AD} 1 \mathrm{P}_{4} \mathrm{FP} 1 \mathrm{FI} 1 \mathrm{~A} 3 \mathrm{C}_{1}\right)$ \\
\hline$\left(\mathrm{AD}_{2} \mathrm{P}_{4 \mathrm{FP}} 1 \mathrm{FP} 1 \mathrm{C}_{1}\right)$ & $(\mathrm{AD} 2 \mathrm{P} 4 \mathrm{FP} 1 \mathrm{FP} 1 \mathrm{~A} 1 \mathrm{C} 1),(\mathrm{AD} 2 \mathrm{P} 4 \mathrm{FP} 1 \mathrm{FP} 1 \mathrm{~A} 2 \mathrm{C} 1),\left(\mathrm{AD} 2 \mathrm{P} 4 \mathrm{FP} 1 \mathrm{FP} 1 \mathrm{~A} 3 \mathrm{C}_{1}\right)$ \\
\hline$\left(\mathrm{AD}_{3} \mathrm{P}_{4 \mathrm{FP}} \mathrm{FI}_{1} \mathrm{C}_{1}\right)$ & $\left(\mathrm{AD}_{3} \mathrm{P}_{4 F P 1 F I 1 A 1 C}\right),\left(\mathrm{AD}_{3} \mathrm{P}_{4} \mathrm{FP} 1 \mathrm{FI} 1 \mathrm{~A} 2 \mathrm{C}_{1}\right),\left(\mathrm{AD}_{3} \mathrm{P}_{4} \mathrm{FP} 1 \mathrm{FI} 1 \mathrm{~A} 3 \mathrm{C}_{1}\right)$ \\
\hline$\left(\mathrm{AD}_{1} \mathrm{P}_{5 \mathrm{FP}} 1 \mathrm{FI} 1 \mathrm{C}_{1}\right)$ & 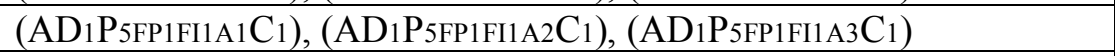 \\
\hline$\left(\mathrm{AD}_{1} \mathrm{P}_{5 \mathrm{FP}} \mathrm{FI} 1 \mathrm{C}_{1}\right)$ & $\left(\mathrm{AD}_{1} \mathrm{P}_{5 \mathrm{FP}} \mathrm{FI} 1 \mathrm{~A} 1 \mathrm{C}_{1}\right),\left(\mathrm{AD}_{1} \mathrm{P}_{5 \mathrm{FP}} \mathrm{F} 1 \mathrm{~A}_{2} \mathrm{C}_{1}\right),\left(\mathrm{AD}_{1} \mathrm{P}_{5 \mathrm{FP}} \mathrm{F}_{1} \mathrm{~A}_{3} \mathrm{C}_{1}\right)$ \\
\hline$\left(\mathrm{AD}_{1} \mathrm{~S}_{1 F P 1 F 11} \mathrm{C}_{1}\right)$ & $\left(\mathrm{AD} 1 \mathrm{~S} 1 \mathrm{FP} 1 \mathrm{FI} 1 \mathrm{A1} \mathrm{C}_{1}\right)$ \\
\hline$\left(\mathrm{AD}_{1} \mathrm{~S}_{2 \mathrm{FP}} \mathrm{FI}_{1} \mathrm{C}_{1}\right)$ & 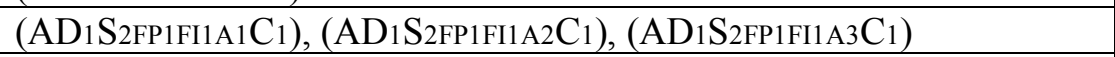 \\
\hline$\left(\mathrm{AD} 1 \mathrm{~S}_{3 \mathrm{FP}} 1 \mathrm{~F} 11 \mathrm{C}_{1}\right)$ & 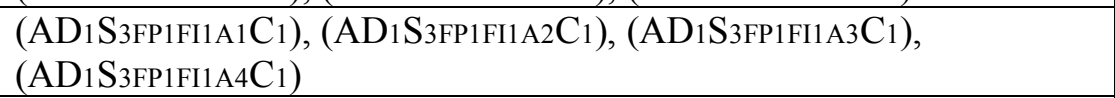 \\
\hline$\left(\mathrm{AD}_{1} \mathrm{~S}_{3 \mathrm{FP}} \mathrm{FI}_{2} \mathrm{C}_{1}\right)$ & 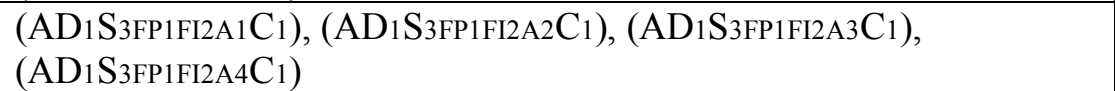 \\
\hline$\left(\mathrm{AD} 1 \mathrm{~S}_{4 \mathrm{FP}} 1 \mathrm{FI} 1 \mathrm{C}_{1}\right)$ & $(\mathrm{AD} 1 \mathrm{~S} 4 \mathrm{FP} 1 \mathrm{FI} 1 \mathrm{~A} 1 \mathrm{C} 1),\left(\mathrm{AD} 1 \mathrm{~S}_{4} \mathrm{FP} 1 \mathrm{FI} 1 \mathrm{~A} 2 \mathrm{C} 1\right)$ \\
\hline$\left(\mathrm{AD} 1 \mathrm{~S}_{4 \mathrm{FP}} 2 \mathrm{FI} 1 \mathrm{C}_{1}\right)$ & $\left(\mathrm{AD}_{1} \mathrm{~S}_{4} \mathrm{FP} 2 \mathrm{FI} 1 \mathrm{~A} 1 \mathrm{C} 1\right),(\mathrm{AD} 1 \mathrm{~S} 4 \mathrm{FP} 2 \mathrm{FI} 1 \mathrm{~A} 1 \mathrm{C} 1),\left(\mathrm{AD} 1 \mathrm{~S}_{4} \mathrm{FP} 2 \mathrm{FI} 1 \mathrm{A1} \mathrm{C}_{1}\right)$ \\
\hline$\left(\mathrm{AD} 1 \mathrm{~S}_{4 \mathrm{FP}} \mathrm{FI} 1 \mathrm{C}_{1}\right)$ & $(\mathrm{AD} 1 \mathrm{~S} 4 \mathrm{FP} 3 \mathrm{~F} 11 \mathrm{A1C} 1)$ \\
\hline$\left(\mathrm{AD} 1 \mathrm{~S}_{5 \mathrm{FP}} 1 \mathrm{~F} 1 \mathrm{C} 1\right)$ & 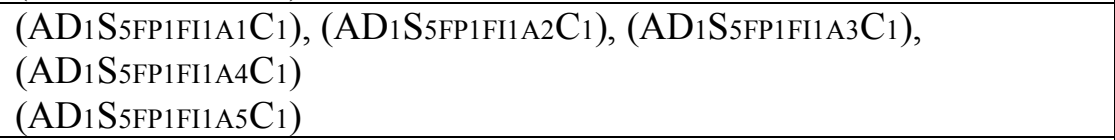 \\
\hline$\left(\mathrm{AD}_{1} \mathrm{~S}_{6 \mathrm{FP}} 1 \mathrm{FI} 1 \mathrm{C} 1\right)$ & $\begin{array}{l}\text { (AD1S6FP1FI1A1C1), (AD1S6FP1FI1A2C1), (AD1S6FP1FI1A3C1), } \\
\left(\mathrm{AD}_{1} \mathrm{~S}_{6 \mathrm{FP} 1 \mathrm{~F} 1 \mathrm{~A} 4 \mathrm{C} 1)}\right.\end{array}$ \\
\hline$\left(\mathrm{AD} 1 \mathrm{~S} 7 \mathrm{FP} 1 \mathrm{FI} 1 \mathrm{C}_{1}\right)$ & $\left(\mathrm{AD}_{1} \mathrm{~S}_{7 F P 1 F 11 A 1 C 1}\right),\left(\mathrm{AD} 1 \mathrm{~S}_{7 F P 1 F I 1 A 2 C}\right),\left(\mathrm{AD} 1 \mathrm{~S}_{7 F P 1 F I 1 A 3 C}\right)$ \\
\hline$\left(\mathrm{AD} 1 \mathrm{~S}_{8 \mathrm{FP} 1 F I 1} \mathrm{C}_{1}\right)$ & 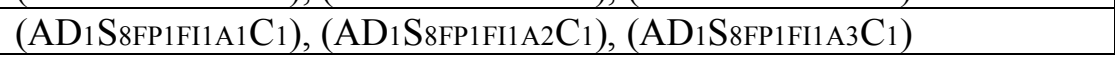 \\
\hline
\end{tabular}

The support factors for each action are persistently grounded on activities in actual practice. For example the investigation probed interviewees unaware a statement made in previous interviews, to validate the support factors for a specific activity of the importance to the supply chain. This stage remained focused on: a) Identifying additional operational activities to assemble the salient areas.

b) Identifying new support resources in the form of operational activities.

\subsection{Factors Driving Supply Chain Design}




\section{Petar Radanliev \\ Architectures for Green-Field Supply Chain Integration \\ Supply Chain Integration Design}

The analysis of the influencing underlying factors, identified a number of similar and distinct features, represented in the supply chain participants from multiple industries. These underlying factors presented, enabled the reviewing the relationship of these visual concepts on shaping a supply chain strategy. This enabled the design of a conceptual map) for applying concepts to integrate the supply chain architecture. The wording has been deleted deliberately to emphasise the process as opposed to the actual case scenario.

Following the same process, the strategic activities are extracted and categorised in groups to narrow the conceptual context).
The coded categories are hierarchically designed to visualise the hierarchical architecture.

\subsection{Formulation and Evaluation $(\mathrm{C} 2,3,4,5)$}

The analysis process of $(\mathrm{CN})$ does not have to be performed in a numerical order because at this stage of the formulation, it is required to determine the support of individual $(\mathrm{ADN})$ to the individual $(\mathrm{SCCN})$ the individual $(\mathrm{SCCNPN})$ and the relationship with the integrated vision (ISV) and integrated goals (IPN) The analysis and evaluation at this stage are performed with individual companies and the recommended process is to complete this task with individual companies as and when suitable, regardless of the numerical order.

TABLE 9. SAMPLE OF THE CONCEPTUAL HIERARCHY SUMMARY MAP

\begin{tabular}{|c|c|c|c|c|}
\hline \multirow[t]{2}{*}{$\left(A D_{1} P_{1} C_{1}\right)$} & \multicolumn{3}{|c|}{ Supply chain processes and outputs } & \\
\hline & $\left(A D_{1} P_{1 F P 1} C_{1}\right)$ & \multicolumn{3}{|c|}{ Diversify logistics chain processes and outputs } \\
\hline & & $\left(A D_{1} P_{1 F P 1 F 11} C_{1}\right)$ & \multicolumn{2}{|c|}{ Pursue supply chain integration } \\
\hline & & & $\left(A D_{1} P_{1 F P 1 F 11 A 1} C_{1}\right)$ & Integrate with 3PLs that can operate on Conwy Valley Line \\
\hline & & & $\left(A D_{1} P_{1 F P 1 F I 1 A 2} C_{1}\right)$ & Integrate with 3PLs that would enable multimodal transport \\
\hline & & & $\left(A D_{1} P_{1 F P} F_{11} A_{3} C_{1}\right)$ & Pursue sea transport through Port of Mostyn \\
\hline
\end{tabular}

\section{TABLE 10. EXAMPLE 1 OF EXTRACTION PROCESS FOR (C3) AREAS OF DECISION}

\begin{tabular}{|c|c|}
\hline Company $\left(\mathrm{C}_{3}\right)$ goal $\left(\mathrm{P}_{1}\right):\left(\mathrm{C}_{3} \mathrm{P}_{1}\right)$ & $\begin{array}{c}\text { Areas of decision }\left(\mathrm{AD}_{1}, \mathbf{2}\right) \text { for }\left(\mathrm{P}_{1} \text { of } \mathrm{C}_{3}\right) \text { : } \\
\left(\mathrm{ADNP} \mathrm{C}_{3}\right)\end{array}$ \\
\hline$\left(\mathrm{C}_{3} \mathrm{P}_{1}\right)$ & $\left(\mathrm{AD}_{1} \mathrm{P}_{1} \mathrm{C}_{3}\right),\left(\mathrm{AD}_{2} \mathrm{P}_{1} \mathrm{C}_{3}\right)$ \\
\hline
\end{tabular}

From $\left(\mathrm{C}_{3} \mathrm{P}_{2}\right)$, three areas were extracted and coded.

TABLE 11. EXAMPLE 2 OF EXTRACTION PROCESS FOR (C3ADN)

\begin{tabular}{|c|c|}
\hline $\begin{array}{c}\text { Company }(\mathbf{C} 3) \text { strategic pillar } \\
\left(\mathbf{P}_{2}\right):\left(\mathbf{C}_{3} \mathbf{P}_{2}\right)\end{array}$ & $\begin{array}{c}\text { Areas of decision }\left(\mathbf{A D}_{1}, \mathbf{2}, \mathbf{3}\right) \text { for }\left(\mathbf{P}_{2} \text { ofC3 }\right): \\
\left(\mathrm{ADN}_{2} \mathbf{P}_{2} \mathbf{C}_{3}\right)\end{array}$ \\
\hline$\left(\mathrm{C}_{3} \mathrm{P}_{2}\right)$ & $\left(\mathrm{AD}_{1} \mathrm{P}_{2} \mathrm{C}_{3}\right),\left(\mathrm{AD}_{2} \mathrm{P}_{2} \mathrm{C}_{3}\right),\left(\mathrm{AD}_{3} \mathrm{P}_{2} \mathrm{C}_{3}\right)$ \\
\hline
\end{tabular}

The outlined process was applied to $\left(\mathrm{C}_{3} \mathrm{PN}\right)$ resulting in the complete list of areas
$(\mathrm{ADNPNC} 3)$. The general statement of the business strategy representing $\left(\mathrm{SCC}_{3}\right)$ represented one of the main obstacles for $\left(\mathrm{C}_{1}\right)$. Their business strategy is investigated in detail 


\section{Petar Radanliev \\ Architectures for Green-Field Supply Chain Integration \\ Supply Chain Integration Design}

resulting in a few closely related concepts that can be applied to the green-field project formulation. These are coded as: $\left(\mathrm{SCC}_{3} \mathrm{P}_{1}\right)$ : ( $\left.\mathrm{SCC}_{3} \mathrm{P}_{2}\right): 3$ ) ( $\left.\mathrm{SCC}_{3} \mathrm{P}_{4}\right):\left(\mathrm{SCC}_{3} \mathrm{P}_{5}\right)$ summarised in Table 14. To visualise the emerging framework, the resulting linkages between $\left(\mathrm{SCC}_{3} \mathrm{PN}_{\mathrm{N}}\right)$ and $\left(\mathrm{ADNPNC}_{3}\right)$ are built and presented into a conceptual diagram (Fig. 1). The construction for (C3) enabled evaluation of the linkages between: the abstract individual areas of decision, the green-field project pillars and the existing individual strategic pillars (Fig. 15).

The method for evaluating the goals of (CN.PN), extracting (AD) from the ideas behind (CN.PN) and categorising goals in the form of $(\mathrm{ADNPN})$, the residual (ADNPNCN) was applied to extract the (AD) from the remaining participants $\left(\mathrm{C}_{2}, \mathrm{C}_{4} \mathrm{C}_{5}\right)$ and was built into a summary map (Table 16). The summary map of extracted $(\mathrm{ADN})$ from the residual $(\mathrm{CN})$ is used to evaluate are the (ADNPNCN) supportive of individual $(\mathrm{SCCNPN})$ and $(\mathrm{CNSC})$ and to evaluate the linkages between the individual company $(\mathrm{ADNPNCN})$ and intercompany (IPN), (ISV). For the evaluation, the complete sample set of $(\mathrm{SCCNPN})$ it is required. This represents the second summary map containing the extraction, validation and evaluation methods applied to evaluate the linkages between $(\mathrm{SCCNPN})$ and (ADNPNCN):

The (ADNPNCN) represent individual areas as categories that enable identification of the tasks and operations, therefore signifying a crucial element in confirming the areas of integrated decision. The (ADNPNCN) must be formulated and evaluated prior to being grouped into concepts for green-field architecture.

\section{DISUSSION}

The aim of this paper was to understand the topic and to develop conceptual architectures for green-field supply chains integration design. In order to achieve this research aim, three specific research objectives are investigated and novel contributions have been made in each of the objectives.

The first objective was to design a set of architectures for categorising individual into integrated business strategies. The paper derived with architectures for green-field project integration with multiple supply chain participants. The architectures are designed with holistic supply chain criteria, highlighting the lack of consideration of this topic in existing literature, particularly in strategy absence scenarios. By exploring the integration vision and goals, the study established categories relating to green-field supply chain integration criteria. This research leads to a more comprehensive understanding of supply chain architecture in the mining industry and in other industries. The attention of many researchers has often focused on a single area of supply chain strategy, while they have generally neglected research on the whole performance of the supply chain. Considering these gaps, objective one for this study established a conceptual architecture, which used the concept of strategic decision making and supply chain integration processes, as the approach to the study of the holistic supply chain architecture. The architectures are designed towards greenfield integration. The concept of green-field integration sets this research apart from methods designed to reformulate existing strategies of individual companies. 


\section{Petar Radanliev}

Architectures for Green-Field Supply Chain Integration

Supply Chain Integration Design

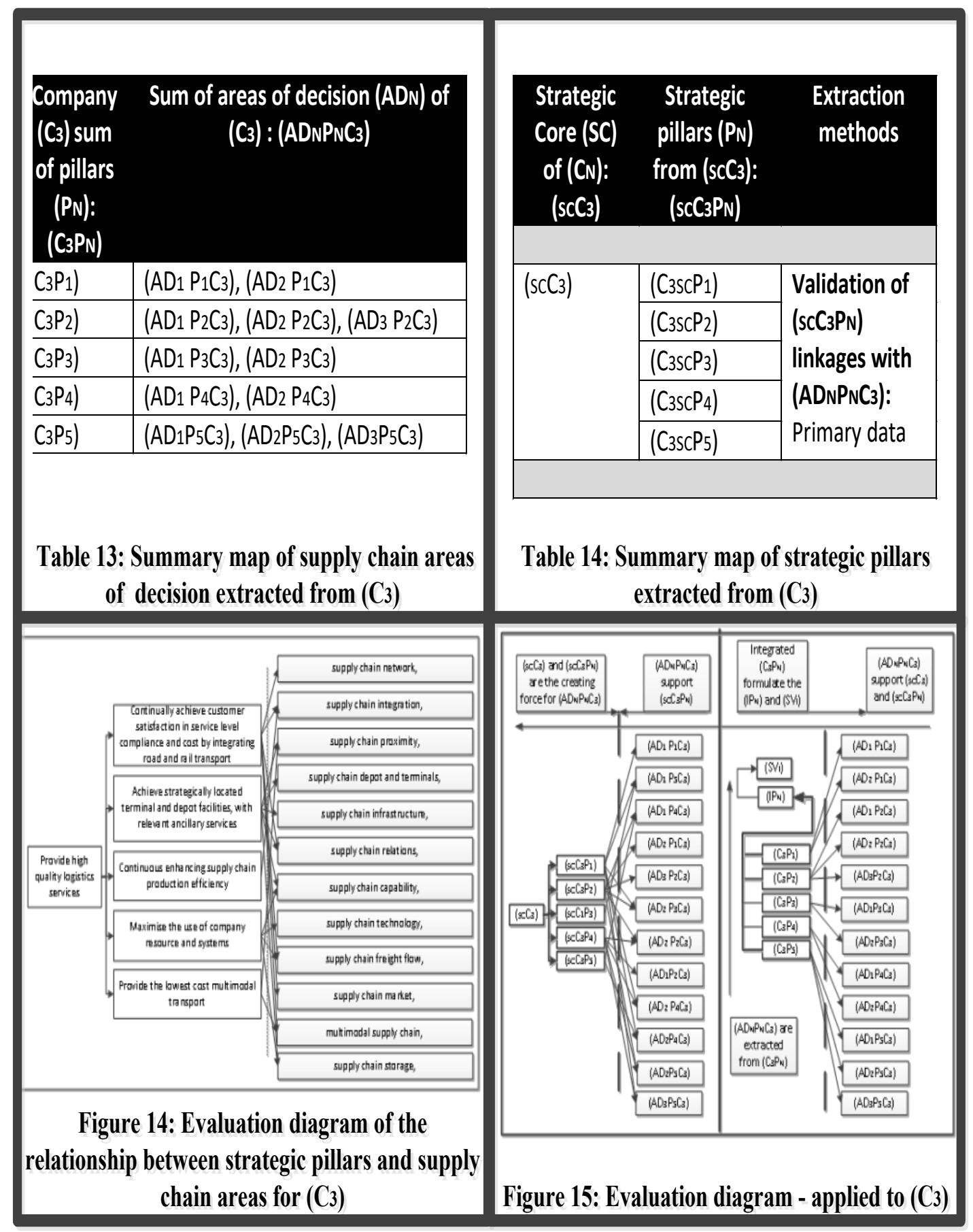




\section{Petar Radanliev}

Architectures for Green-Field Supply Chain Integration

Supply Chain Integration Design

\begin{tabular}{|c|c|c|c|c|}
\hline \multicolumn{2}{|c|}{$\left(\mathrm{CN}_{\mathrm{N} N}\right) \quad\left(\mathrm{ADNC} \mathrm{C}_{\mathrm{N}}\right)$} & \multirow{5}{*}{$\begin{array}{l}\text { Strategic } \\
\text { Core } \\
(\mathrm{SC}) \text { of } \\
\left(\mathrm{CN}_{\mathrm{N}}\right) \\
\left(\mathrm{Sc} \mathrm{C}_{\mathrm{N}}\right)\end{array}$} & \multirow{4}{*}{$\begin{array}{l}\text { Strategic pillars } \\
(\mathrm{PN}) \text { from }\left(\mathrm{sc} \mathrm{CN}_{\mathrm{N}}\right) \text { : } \\
\left(\mathrm{sc} \mathrm{C}_{\mathrm{N} N \mathrm{~N}}\right)\end{array}$} & \multirow{5}{*}{$\begin{array}{l}\text { Extraction and } \\
\text { validation }\end{array}$} \\
\hline$\left(\mathrm{C}_{1} \mathrm{PN}_{\mathrm{N}}\right)$ & $\left(A D_{N} C_{1}\right)$ & & & \\
\hline$\left(\mathrm{C}_{1} \mathrm{P}_{1}\right)$ & $\left(A D_{1} P_{1} C_{1}\right),\left(A D_{2} P_{1} C_{1}\right),\left(A D_{3} P_{1} C_{1}\right),\left(A D_{4} P_{1} C_{1}\right)$ & & & \\
\hline$\left(\mathrm{C}_{1} \mathrm{P}_{2}\right)$ & $\left(A D_{1} P_{2} C_{1}\right)$ & & & \\
\hline$\left(\mathrm{C}_{1} \mathrm{P}_{3}\right)$ & $\left(\mathrm{AD}_{1} \mathrm{P}_{3} \mathrm{C}_{1}\right)$ & & & \\
\hline$\left(\mathrm{C}_{1} \mathrm{P}_{4}\right)$ & $\left(A_{1} P_{4} C_{1}\right),\left(A D_{2} P_{4} C_{1}\right),\left(A D_{3} P_{4} C_{1}\right)$ & \multirow[t]{4}{*}{$(\mathrm{scC} 1)$} & $\left(\mathrm{C}_{1 s c} \mathrm{P}_{1}\right)$ & \multirow{4}{*}{$\begin{array}{l}\text { Secondary and } \\
\text { primary data }\end{array}$} \\
\hline$\left(\mathrm{C}_{1} \mathrm{P}_{5}\right)$ & $\left(\mathrm{AD}_{1} \mathrm{P}_{5} \mathrm{C}_{1}\right)$ & & $\left(\mathrm{C}_{15 c} \mathrm{P}_{3}\right)$ & \\
\hline \multirow[t]{2}{*}{$\left(\mathrm{C}_{1} \mathrm{P}_{6}\right)$} & $\left(A_{2} P_{6} C_{1}\right)$ & & $\left(\mathrm{C}_{15} \mathrm{CP}_{4}\right)$ & \\
\hline & $\left(A D N C_{2}\right)$ & & $\left(\mathrm{C}_{15} \mathrm{CP}_{5}\right)$ & \\
\hline$\frac{\left(C_{2}+\mathrm{V}_{1}\right)}{\left(\mathrm{C}_{2} \mathrm{P}_{1}\right)}$ & $\frac{\left(A D N C_{2}\right)}{\left(A_{1} P_{1} C_{2}\right)}$ & \multirow{6}{*}{$\left(s c C_{2}\right)$} & & \multirow{6}{*}{$\begin{array}{l}\text { Secondary and } \\
\text { primary data }\end{array}$} \\
\hline$\left(\mathrm{C}_{2} \mathrm{P}_{2}\right)$ & $\left(\mathrm{AD}_{1} \mathrm{P}_{2} \mathrm{C}_{2}\right)$ & & $\left(\mathrm{C}_{2} \mathrm{~s}_{\mathrm{C}} \mathrm{P}_{1}\right)$ & \\
\hline$\left(\mathrm{C}_{2} \mathrm{P}_{3}\right)$ & $\left(\mathrm{AD}_{1} \mathrm{P}_{2} \mathrm{C}_{2}\right),\left(\mathrm{AD}_{2} \mathrm{P}_{2} \mathrm{C}_{2}\right),\left(\mathrm{AD}_{3} \mathrm{P}_{2} \mathrm{C}_{2}\right)$ & & $\left(\mathrm{C}_{2} \mathrm{SC}_{2}\right)$ & \\
\hline$\left(\mathrm{C}_{2} \mathrm{P}_{4}\right)$ & $\left(\mathrm{AD}_{1} \mathrm{P}_{4} \mathrm{C}_{2}\right)$ & & $\left(\mathrm{C}_{2} \mathrm{SCP}_{3}\right)$ & \\
\hline$\left(\mathrm{C}_{2} \mathrm{P}_{5}\right)$ & $\left(\mathrm{AD}_{1} \mathrm{P}_{5} \mathrm{C}_{2}\right)$ & & $\left(\mathrm{C}_{2} \mathrm{SCP}_{4}\right)$ & \\
\hline$\left(\mathrm{C}_{2} \mathrm{P}_{6}\right)$ & $\left(\mathrm{AD}_{1} \mathrm{P}_{6} \mathrm{C}_{2}\right)$ & & $\left(\mathrm{C}_{25} \mathrm{SP}_{5}\right)$ & \\
\hline$\left(\mathrm{C}_{2} \mathrm{P}_{7}\right)$ & $\left(\mathrm{AD}_{1} \mathrm{P}_{7} \mathrm{C}_{2}\right)$ & \multirow{6}{*}{$(\mathrm{scC} 3)$} & & \\
\hline 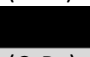 & & & $\left(\mathrm{C}_{3 s c} \mathrm{P}_{1}\right)$ & \multirow{5}{*}{$\begin{array}{l}\text { Secondary and } \\
\text { primary data }\end{array}$} \\
\hline$\left(\mathrm{C}_{3} \mathrm{PN}\right)$ & $(\mathrm{ADNC} 3)$ & & $\left(\mathrm{C}_{3 \mathrm{SC}} \mathrm{P}_{2}\right)$ & \\
\hline$\left(\mathrm{C}_{3} \mathrm{P}_{1}\right)$ & $\left(A_{1} P_{1} C_{3}\right),\left(A D_{2} P_{1} C_{3}\right)$ & & $\left(\mathrm{C}_{3 \mathrm{~S}} \mathrm{P}_{3}\right)$ & \\
\hline$\left(\mathrm{C}_{3} \mathrm{P}_{2}\right)$ & $\left(A D_{1} P_{2} C_{3}\right),\left(A D_{2} P_{2} C_{3}\right),\left(A D_{3} P_{2} C_{3}\right)$ & & $\left(\mathrm{C}_{3 \mathrm{SCP}} \mathrm{C}\right)$ & \\
\hline$\left(\mathrm{C}_{3} \mathrm{P}_{3}\right)$ & $\left(A_{1} P_{3} C_{3}\right),\left(A_{2} P_{3} C_{3}\right)$ & & $\left(\mathrm{C}_{3} \mathrm{sc}_{5}\right)$ & \\
\hline$\left(\mathrm{C}_{3} \mathrm{P}_{4}\right)$ & $\left(\mathrm{AD}_{1} \mathrm{P}_{4} \mathrm{C}_{3}\right),\left(\mathrm{AD}_{2} \mathrm{P}_{4} \mathrm{C}_{3}\right)$ & \multirow{4}{*}{$\left(\mathrm{scC}_{4}\right)$} & & \\
\hline \multirow{2}{*}{$\left(\mathrm{C}_{3} \mathrm{P}_{5}\right)$} & $\left(\mathrm{AD}_{1} \mathrm{P}_{5} \mathrm{C}_{3}\right),\left(\mathrm{AD}_{2} \mathrm{P}_{5} \mathrm{C}_{3}\right),\left(\mathrm{AD}_{3} \mathrm{P}_{5} \mathrm{C}_{3}\right)$ & & $\left(\mathrm{C}_{4 \mathrm{SC}} \mathrm{P}_{1}\right)$ & \multirow{3}{*}{$\begin{array}{l}\text { Secondary and } \\
\text { primary data }\end{array}$} \\
\hline & & & $\left(\mathrm{C}_{4 S C P}\right)$ & \\
\hline$\left(\mathrm{C}_{4} \mathrm{PN}\right)$ & $\left(\mathrm{ADNC}_{4}\right)$ & & $\left(\mathrm{C}_{4 S C} \mathrm{P}_{3}\right)$ & \\
\hline$\left(\mathrm{C}_{4} \mathrm{P}_{1}\right)$ & $\left(\mathrm{AD}_{1} \mathrm{P}_{1} \mathrm{C}_{4}\right),\left(\mathrm{AD} 2 \mathrm{P}_{1} \mathrm{C}_{4}\right),\left(\mathrm{AD} \mathrm{D}_{1} \mathrm{P}_{1} \mathrm{C}_{4}\right)$ & \multirow{5}{*}{$\left(\mathrm{scC}_{5}\right)$} & $\left(\mathrm{C}_{5 \mathrm{sc}} \mathrm{P}_{1}\right)$ & \multirow{5}{*}{ Primary data } \\
\hline$\left(\mathrm{C}_{4} \mathrm{P}_{2}\right)$ & $\left(\mathrm{AD}_{1} \mathrm{P}_{2} \mathrm{C}_{4}\right),\left(\mathrm{AD}_{2} \mathrm{P}_{2} \mathrm{C}_{4}\right)$ & & $\left(\mathrm{C}_{5 s c} \mathrm{P}_{2}\right)$ & \\
\hline$\left(\mathrm{C}_{4} \mathrm{P}_{3}\right)$ & $\left(\mathrm{AD}_{1} \mathrm{P}_{3} \mathrm{C}_{4}\right),\left(\mathrm{AD}_{2} \mathrm{P}_{3} \mathrm{C}_{4}\right)$ & & $\left(\mathrm{C}_{5 s c} \mathrm{P}_{3}\right)$ & \\
\hline$\left(\mathrm{C}_{4} \mathrm{P}_{4}\right)$ & $\left(\mathrm{AD}_{1} \mathrm{P}_{4} \mathrm{C}_{4}\right),\left(\mathrm{AD}_{2} \mathrm{P}_{4} \mathrm{C}_{4}\right)$ & & $\left(\mathrm{C}_{5 s} \mathrm{CP}_{4}\right)$ & \\
\hline$\left(\mathrm{C}_{4} \mathrm{P}_{5}\right)$ & $\left(\mathrm{AD}_{2} \mathrm{P}_{5} \mathrm{C}_{4}\right)$ & & $\left(\mathrm{C}_{5 \mathrm{SC}} \mathrm{P}_{5}\right)$ & \\
\hline$\left(\mathrm{C}_{4} \mathrm{P}_{6}\right)$ & $\left(\mathrm{AD} 1 \mathrm{P}_{6} \mathrm{C}_{4}\right)$ & \multirow{15}{*}{\multicolumn{3}{|c|}{$\begin{array}{c}\text { Table 17: Summary map of individual strategic } \\
\text { pillars extracted from }(\mathrm{CN})\end{array}$}} \\
\hline$\left(\mathrm{C}_{4} \mathrm{P}_{7}\right)$ & $\left(\mathrm{AD}_{1} \mathrm{P}_{7} \mathrm{C}_{4}\right),\left(\mathrm{AD} 2 \mathrm{P}_{7} \mathrm{C}_{4}\right),\left(\mathrm{AD}{ }_{3} \mathrm{P}_{7} \mathrm{C}_{4}\right)$ & & & \\
\hline$\left(\mathrm{C}_{3} \mathrm{PN}\right)$ & $\left(\mathrm{ADNC}_{3}\right)$ & & & \\
\hline$\left(\mathrm{C}_{3} \mathrm{P}_{1}\right)$ & $\left(A D_{1} P_{1} C_{3}\right),\left(A D_{2} P_{1} C_{3}\right)$ & & & \\
\hline$\left(\mathrm{C}_{3} \mathrm{P}_{2}\right)$ & $\left(A D_{1} P_{2} C_{3}\right),\left(A D_{2} P_{2} C_{3}\right),\left(A D_{3} P_{2} C_{3}\right)$ & & & \\
\hline$\left(\mathrm{C}_{3} \mathrm{P}_{3}\right)$ & $\left(A D_{1} P_{3} C_{3}\right),\left(A D_{2} P_{3} C_{3}\right)$ & & & \\
\hline$\left(\mathrm{C}_{3} \mathrm{P}_{4}\right)$ & $\left(A D_{1} P_{4} C_{3}\right),\left(A D_{2} P_{4} C_{3}\right)$ & & & \\
\hline$\left(\mathrm{C}_{3} \mathrm{P}_{5}\right)$ & $\left(A_{1} P_{5} C_{3}\right),\left(A_{2} P_{5} C_{3}\right),\left(A D_{3} P_{5} C_{3}\right)$ & & & \\
\hline$\left(\mathrm{C}_{5} \mathrm{PN}\right)$ & (ADNC5) & & & \\
\hline$\left(\mathrm{C}_{5} \mathrm{P}_{1}\right)$ & $\left(A D_{1} P_{1} C_{5}\right),\left(A D_{2} P_{1} C_{5}\right)$ & & & \\
\hline$\left(\mathrm{C}_{5} \mathrm{P}_{2}\right)$ & $\left(A_{1} P_{2} C_{5}\right),\left(A_{2} P_{2} C_{5}\right),\left(A_{3} P_{2} C_{5}\right)$ & & & \\
\hline$\left(\mathrm{C}_{5} \mathrm{P}_{3}\right)$ & $\left(\mathrm{AD}_{2} \mathrm{P}_{3} \mathrm{C}_{5}\right)$ & & & \\
\hline$\left(\mathrm{C}_{5} \mathrm{P}_{4}\right)$ & $\left(\mathrm{AD}_{1} \mathrm{P}_{4} \mathrm{C}_{5}\right)$ & & & \\
\hline (C5 $\left.\mathrm{C}_{5}\right)$ & $\left(A_{1} P_{5} C_{5}\right),\left(A_{2} P_{5} C_{5}\right)$ & & & \\
\hline \multicolumn{2}{|c|}{$\begin{array}{l}\text { Table 16: Conceptual summary map resulting from the } \\
\text { valuation of the relationship between individual strategic } \\
\text { goals and individual areas of decision from }(\mathrm{CN})\end{array}$} & & & \\
\hline
\end{tabular}




\section{Petar Radanliev \\ Architectures for Green-Field Supply Chain Integration \\ Supply Chain Integration Design}

The second objective was to advance the individual architectures into integration design. The paper developed a conceptual design for systematically prioritising individual activities, towards pre-defined supply chain integration areas. The paper firstly conceptualised supply chain architecture as a system of choices, patterns or decisions. The operational aspects of integration design were categorised in the conceptual architectures. The design process established that reaching a consensus on the action objectives and strategic activities is required to enable the integration designs. The investigation into the operational activities was focused on avoiding prescriptive and descriptive approaches and addressed the operationalization aspects of supply chain architecture. The case study determined that the supply chain and competitive strategy were not linked in the case study investigated. Therefore, the findings from the case study strengthened the argument that failures of adapting supply chain principles and aligning operations are still strongly present in industry. The second novelty of the research is that the conceptual architecture developed in this paper addressed the issues of aligning and adapting.

The third objective was to design a conceptual system for green-field supply chain integration architecture and to resolve business problems emerging from the supply chain integration. The paper derived and validated the conceptual system by applying it to the case study participants in the mining industry. The conceptual system was designed to be a more integrative, comprehensive and relational than others developed in the literature on supply chain reformulation. The conceptual system investigates a holistic perspective of green-field architecture. There are significant differences, between the conceptual system in this paper and existing models, which were lacking the notion of integrated core strategy and are based on causality among the concepts (Schnetzler et al., 2007, Perez-Franco et al., 2010). Nevertheless, these corresponding models have provided significant background understanding for the creation of the new architectures. This paper further contributed to knowledge in the field of supply chain by successfully implementing the additional aspect of integrating a consortium in a green-field architecture. The findings of this paper concluded that strategy architecture represents a process of accepting the reality and acting upon that reality, by designing patterns of choices and evaluating the outcome of these choices.

The research examined three main industrial groups related to the mining industry: transportation, logistics, and civil engineering. The industry groups were selected on the basis of the representativeness of the main industry groups related to the mining industry. The analysis of the research is based on the empirical data, collected through the case study and is purely based on contribution to knowledge and academic advancement.

\section{CONCLUSION}

This paper derived with a set of architectures for clarifying and eliminating conflicts in green-field supply chain integration. The strength of the green-field architectures is the ability to convert such problems into a different format, which is easily visualised and easily addressed. The objective of the process was to formulate integrated strategy imprinted by all the participants in the supply chain. The process resulted in building a new integration architecture. The process of categorising individual supply chain strategic architectures was aimed at defining the supply chain integration process as a system.

The conceptual architecture represented a method for explicit integration design. The conceptual architecture derives with new insights from tacit knowledge, and enables the formulation of a green-field supply chain strategy.

The architecture aspect in this research paper is advancing in analysing the relationship 


\section{Petar Radanliev \\ Architectures for Green-Field Supply Chain Integration \\ Supply Chain Integration Design}

between the individual and the integrated vision and goals and focusing towards achieving the individual and the integrated goals of the participants. The process advocates tapping into the salient areas and principles to solve the predefined critical problems related to the conversion of tacit into explicit knowledge.

Formulating a green-field supply chain strategy will in most cases result in multiple conflicts of interest in the design process. The framework eliminates such conflict of interest, and through applying the concepts into the conceptual architectures, the formulation retains only the feasible concepts.

The novelty of the conceptual architectures is that they automatically eliminate conflicts of interest. The architectures also eliminate unfeasible concepts that lack authentic validity, while in the same time, allow for an area to be filled if concepts are expected to be explicit, but are left in implicit form and present the strategy in a clear and visual method. The architecture represents a method that can be used by supply chain practitioners in the process of formulating green-field supply chain integration strategies. This research is part of research paper series related to this topic (Nicolescu, Huth, Radanliev, \& De Roure, 2018b; Nurse, Radanliev, Creese, \& De Roure, 2018; P. Radanliev et al., 2018; P. Radanliev, De Roure, Nicolescu, \& Huth, 2019; P Radanliev et al., 2018; Petar Radanliev, 2019a, 2019b, 2014, 2015a, 2015c, 2015b, 2016; Petar Radanliev et al., 2019; Petar Radanliev, Charles De Roure, Nurse, Burnap, \& Montalvo, 2019; Petar Radanliev et al., 2019, 2018, 2019, 2019, 2019, 2019, 2019, 2019, 2019; Petar Radanliev, Rowlands, \& Thomas, 2014; Petar Radanliev, De Roure, Nurse, Montalvo, \& Burnap, 2019a, 2019b; Petar Radanliev, De Roure, Cannady, et al., 2019)(Nicolescu, Huth, Radanliev, \& De Roure, 2018a; Petar Radanliev, De Roure, Nurse, Rafael, \& Burnap, 2019; Petar Radanliev et al., 2019, 2019; Taylor, P., Allpress, S., Carr, M., Lupu, E., Norton, J., Smith et al., 2018).

\section{REFERENCES}

Al-Mudimigh, A. S., Zairi, M., and Ahmed, A. M. M. 2004. Extending the concept of supply chain: The effective management of value chains. International Journal of Production Economics, 87(3), pp.309320.

Bozarth, C.C., Warsinga, D.P., Flynnb, B.B., Flynn, E.J. 2009. The impact of supply chain complexity on manufacturing plant performance. Journal of Operations Management, 27(1), pp.78-93.

Childerhouse, P., and Towill, D. R. 2011. Arcs of supply chain integration. International Journal of Production Research, 49(24), pp.7441-7468.

Frohlich, M. and Westbrook, R. 2001. Arcs of Integration: An International Study of Supply Chain Strategies. Journal of Operations Management. 19 (2001), pp. 185-200.

Gilley, K. M., and Rasheed, A. 2000. Making More by Doing Less: An Analysis of Outsourcing and its Effects on Firm Performance. Journal of Management, 26(4), pp.763-790.

He, Y., and Lai, K. K. 2012. Supply chain integration and service oriented transformation: Evidence from Chinese equipment manufacturers. International Journal of Production Economics, 135(2), pp.791-799.

Ivanov, D. 2010. An adaptive framework for aligning (re)planning decisions on supply chain strategy, design, tactics, and operations. International Journal of Production Research, 48(13), pp.39994017.

Jayaram, J. and Tan, K.C. 2010. Supply Chain Integration with Third-Party Logistics Providers. International Journal of Production Economics, 125 (2), pp. 262271. 


\section{Petar Radanliev \\ Architectures for Green-Field Supply Chain Integration \\ Supply Chain Integration Design}

Kim, D. 2006. Process chain: A new paradigm of collaborative commerce and synchronized supply chain. Business Horizons, 49(5), pp.359-367.

Manthou, V., Vlachopoulou, M., and Folinas, D. 2004. Virtual e-Chain $(\mathrm{VeC})$ model for supply chain collaboration. International Journal of Production Economics, 87(3), pp. 241-250.

Mckone-Sweet, K. and Lee, Y.T. 2009. Development and Analysis of a Supply Chain Strategy Taxonomy. Journal of Supply Chain Management, 45(3), pp.324.

Martínez-Olvera, C., and Shunk, D. 2006. Comprehensive framework for the development of a supply chain strategy. International Journal of Production Research, 44(21), pp. 4511-4528.

Martínez-Olvera, C. 2008. Methodology for realignment of supply-chain structural elements. International Journal of Production Economics, 114(2), pp.714722.

Melnyk, S. A., Narasimhan, R., and DeCampos, H. A. 2013. Supply chain design: issues, challenges, frameworks and solutions. International Journal of Production Research, 52(7), pp.18871896.

Mentzer, J.T., DeWitt, W., Keebler, J.S., Min. S., Nix, N.W., Smith, C.D., Zacharia, Z.G. 2001. Defining supply chain management. Journal of Business Logistics, 22(2), pp.1-25.

Narasimhan, R., and Kim, S. W. 2002. Effect of supply chain integration on the relationship between diversification and performance: evidence from Japanese and Korean firms. Journal of Operations Management, 20(3), pp.303-323.

Narasimhan, R., Kim, S.W. and Tan, K.C. 2008. An Empirical investigation of supply chain strategy typologies and relationships to performance. International Journal of
Production Research, 46(18), pp.5231 5259.

Nikulin, C., Graziosi, S., Cascini, G., Araneda, A., and Minutolo, M. 2013. An algorithm for supply chain integration based on OTSM-TRIZ. Procedia - Social and Behavioral Sciences, 75, pp.383-396.

Pathak, S. D., Day, J. M., Nair, A., Sawaya, W. J., and Kristal, M. M. 2007. Complexity and adaptivity in supply networks: building supply network theory using a complex adaptive systems perspective. Decision Sciences, 38(4), pp.547-580.

Perez - Franco, R. J, Sheffi, Y. Silbey, S., Frey, D., Singh, M., Leveson, N. 2010. A methodology to capture, evaluate and reformulate a firm's supply chain strategy as a conceptual system. PhD Thesis, MIT Press

Prajogo, D., and Olhager, J. 2012. Supply chain integration and performance: The effects of long-term relationships, information technology and sharing, and logistics integration. International Journal of Production Economics, 135(1), pp.514522.

Radanliev, P., Rowlands, H. and Thomas, A. 2014. Supply Chain Paradox: Green-field Architecture for Sustainable Strategy Formulation. Proceedings - Cardiff: SDM'2014 International Conference on Sustainable Design and Manufacturing. Cardiff, Wales, UK, 28-30 April 2014, Future Press Technology, pp. 839-851.

Radanliev, P. 2015. Green-field Architecture for Sustainable Strategy Formulation. International Journal of Supply Chain Management, 4(2), pp.62-67.

Radanliev, P. 2016. Supply Chain Systems Architecture and Engineering Design: Green-field Supply Chain Integration. Operations and Supply Chain Management: An International Journal, 9(1), pp.22-30.

Rosenzweig, E. D. Roth, A. V, and Dean, J. W. 2003. The influence of an integration 


\section{Petar Radanliev \\ Architectures for Green-Field Supply Chain Integration \\ Supply Chain Integration Design}

strategy on competitive capabilities and business performance: An exploratory study of consumer products manufacturers. Journal of Operations Management, 21(4), pp.437-456.

Saad, M., Jones, M., and James, P. 2002. A review of the progress towards the adoption of supply chain management (SCM) relationships in construction. European Journal of Purchasing and Supply Management, 8(3), pp.173-183.

Schnetzler, M.J., Sennheiser, A. and Schönsleben, P. 2007. A decompositionbased approach for the development of a supply chain strategy. International Journal of Production Economics, 105(1), pp.21-42.

Swink, M., Narasimhan, R., and Wang, C. 2007. Managing beyond the factory walls: Effects of four types of strategic integration on manufacturing plant performance. Journal of Operations Management, 25(1), pp.148-164.

Van der Vaart, T., and van Donk, D. P. 2008. A critical review of survey-based research in supply chain integration. International Journal of Production Economics, 111(1), pp.42-55.

Vickery, S. K., Jayaram, J., Droge, C., and Calantone, R. (2003). The effects of an integrative supply chain strategy on customer service and financial performance: an analysis of direct versus indirect relationships. Journal of Operations Management, 21(5), pp.523539.

Nicolescu, R., Huth, M., Radanliev, P., \& De Roure, D. (2018a). Mapping the values of IoT. Journal of Information Technology, 1-16. https://doi.org/10.1057/s41265-0180054-1

Nicolescu, R., Huth, M., Radanliev, P., \& De Roure, D. (2018b). State of The Art in IoT - Beyond Economic Value. Retrieved from https://iotuk.org.uk/wp-
content/uploads/2018/08/State-of-the-Artin-IoT--Beyond-Economic-Value2.pdf

Nurse, J. R. C., Radanliev, P., Creese, S., \& De Roure, D. (2018). Realities of Risk: 'If you can't understand it, you can't properly assess it!': The reality of assessing security risks in Internet of Things systems. Living in the Internet of Things: Cybersecurity of the IoT - 2018, 1-9. https://doi.org/10.1049/cp.2018.0001

Radanliev, P. (2014). A conceptual framework for supply chain systems architecture and integration design based on practice and theory in the North Wales slate mining industry (British Library). https://doi.org/ISNI: 0000000453526866 Radanliev, P. (2015a). Architectures for Digital Supply Chain Integration. Journal of Supply Chain and Operations Management, 13(2). Retrieved from https://www.csupom.com/uploads/1/1/4/8 $/ 114895679 / 2015 n 5 p 5 . p d f$

Radanliev, P. (2015b). Engineering Design Methodology for Digital Supply Chain Architectures Taxonomic Scheme. Journal of Operations and Supply Chain Management, 8(2), 52-66. https://doi.org/10.12660/joscmv8n2p5266

Radanliev, P. (2015c). Digital Architecture for Sustainable Supply Chain Strategy Formulation. International Journal of Supply Chain Management, 4(2), 62-67. Retrieved from http://ojs.excelingtech.co.uk/index.php/IJ $\mathrm{SCM} /$ article/view/1060/pdf

Radanliev, P. (2016). Supply Chain Systems Architecture and Engineering Design: Digital Supply Chain Integration. Operations and Supply Chain Management: An International Journal, 9(1). Retrieved from http://www.journal.oscmforum.org/journal/abstract/oscm-volume9-issue-1-2016/supply-chain-systems- 


\section{Petar Radanliev \\ Architectures for Green-Field Supply Chain Integration \\ Supply Chain Integration Design}

architecture-and-engineering-design-

digital-supply-chain-integration

Radanliev, P. (2019a). CYBER RISK IMPACT ASSESSMENT. University of Oxford.

Radanliev, P. (2019b). Cyber Risk Management for the Internet of Things. University of Oxford.

Radanliev, P., Charles De Roure, D., Maple, C., Nurse, J. R. C., Nicolescu, R., \& Ani, U. (2019). Cyber Risk in IoT Systems. In Journal of Cyber Policy. https://doi.org/10.13140/RG.2.2.29652.86 404

Radanliev, P., Charles De Roure, D., Nurse, J. R. C., Burnap, P., \& Montalvo, R. M. (2019). Methodology for designing decision support supply chain systems for visualising and mitigating cyber risk from IoT technologies. In Working paper. https://doi.org/10.13140/RG.2.2.32975.53 921

Radanliev, P., De Roure, C. D., Nurse, .R.C., Nicolescu, R., Huth, M., Cannady, C., \& Montalvo, R. M. (2018). Integration of Cyber Security Frameworks, Models and Approaches for Building Design Principles for the Internet-of-things in Industry 4.0. Living in the Internet of Things: Cybersecurity of the IoT - 2018, (CP740), 41 (6 1 pp.)-41 (6 1 pp.). https://doi.org/10.1049/cp.2018.0041

Radanliev, P., De Roure, D. C., Nurse, J. R. C. C., Nicolescu, R., Huth, M., Cannady, S., \& Montalvo, R. M. (2019). New developments in Cyber Physical Systems, the Internet of Things and the Digital Economy - future developments in the Industrial Internet of Things and Industry 4.0 .

https://doi.org/10.13140/RG.2.2.14133.93 921

Radanliev, P., De Roure, D. C., Nurse, J. R. C., Montalvo, R. M., \& Burnap, P. (2019a). Standardisation of cyber risk impact assessment for the Internet of Things (IoT).
https://doi.org/10.13140/RG.2.2.27903.05 280

Radanliev, P., De Roure, D. C., Nurse, J. R. C., Montalvo, R. M., \& Burnap, P. (2019b). The Industrial Internet-of-Things in the Industry 4.0 supply chains of small and medium sized enterprises. In Working paper.

https://doi.org/10.13140/RG.2.2.14140.49 283

Radanliev, P., De Roure, D. C., Nurse, J. R. C., Rafael, M. M., \& Burnap, P. (2019). Supply Chain Design for the Industrial Internet of Things and the Industry 4.0. https://doi.org/10.13140/RG.2.2.36311.32 160

Radanliev, P., De Roure, D., Cannady, S., Montalvo, R. ., Nicolescu, R., \& Huth, M. (2018). Economic impact of IoT cyber risk - analysing past and present to predict the future developments in IoT risk analysis and IoT cyber insurance. Living in the Internet of Things: Cybersecurity of the IoT - 2018, (CP740), 3 (9 pp.). https://doi.org/10.1049/cp.2018.0003

Radanliev, P., De Roure, D., Cannady, S., Montalvo, R. M., Nicolescu, R., \& Huth, M. (2019). Analysing IoT cyber risk for estimating IoT cyber insurance. https://doi.org/10.13140/RG.2.2.25006.36 167

Radanliev, P., De Roure, D., Nicolescu, R., \& Huth, M. (2019). A reference architecture for integrating the Industrial Internet of Things in the Industry 4.0. In Working paper.

https://doi.org/10.13140/RG.2.2.26854.47 686

Radanliev, P., De Roure, D., Nicolescu, R., Huth, M., Montalvo, R. M., Cannady, S., \& Burnap, P. (2018). Future developments in cyber risk assessment for the internet of things. Computers in Industry, 102, 14-22. https://doi.org/10.1016/J.COMPIND.2018 .08 .002 


\section{Petar Radanliev}

Architectures for Green-Field Supply Chain Integration

Supply Chain Integration Design

Radanliev, P., De Roure, D., Nurse, J. R., Burnap, P., Anthi, E., Ani, U., ... Mantilla Montalvo, R. (2019). Cyber risk from IoT technologies in the supply chaindiscussion on supply chains decision support system for the digital economy. University of Oxford. https://doi.org/10.13140/RG.2.2.17286.22 080

Radanliev, P., De Roure, D., Nurse, J. R. C. C., Nicolescu, R., Huth, M., Cannady, S., \& Montalvo, R. M. (2019). Cyber risk impact assessment - assessing the risk from the IoT to the digital economy. https://doi.org/10.13140/RG.2.2.11145.49 768

Radanliev, P., De Roure, D., Nurse, J. R. C., Nicolescu, R., Huth, M., Cannady, S., \& Montalvo, R. M. (2019). Cyber Security Framework for the Internet-of-Things in Industry https://doi.org/10.13140/RG.2.2.32955.87 845

Radanliev, P., DeRoure, D., Nurse, J. R. C., Burnap, P., Anthi, E., Ani, U., ... Montalvo, R. M. (2019). Definition of Cyber Strategy Transformation Roadmap for Standardisation of IoT Risk Impact Assessment with a Goal-Oriented Approach and the Internet of Things Micro Mart. In Working paper. https://doi.org/10.13140/RG.2.2.12462.77 124

Radanliev, P., Roure, D. C. De, Nurse, J. R. C., Burnap, P., Anthi, E., Ani, U., ... Montalvo, R. M. (2019). Cyber risk from IoT technologies in the supply chain decision support system for the Industry 4.0.

https://doi.org/10.13140/RG.2.2.17286.22 080

Radanliev, P., Roure, D. C. De, Nurse, J. R. C., Burnap, P., Anthi, E., Ani, U., ... Montalvo, R. M. (2019). Definition of Internet of Things (IoT) Cyber Risk Discussion on a Transformation Roadmap for Standardisation of Regulations, Risk Maturity, Strategy Design and Impact Assessment (No. 201903.0080.v1). https://doi.org/10.13140/RG.2.2.17305.88 167

Radanliev, P., Roure, D. C. De, Nurse, J. R. C., Burnap, P., Eirini Anthi, Ani, U., ... Montalvo, R. M. (2019). Design principles for cyber risk impact assessment from Internet of Things (IoT). In Wokring paper.

https://doi.org/10.13140/RG.2.2.33014.86 083

Radanliev, P., Roure, D. De, Nurse, J. R. C., Nicolescu, R., Huth, M., Cannady, S., \& Montalvo, R. M. (2019). Cyber Risk impact Assessment - Assessing the Risk from the IoT to the Digital Economy. University of Oxford. https://doi.org/10.20944/PREPRINTS201 903.0109.V1

Radanliev, P., Roure, D. De, Nurse, J. R. C., Nicolescu, R., Huth, M., Cannady, S., \& Montalvo, R. M. (2019). New Developments in Cyber Physical Systems, the Internet of Things and the Digital Economy - Discussion on Future Developments in the Industrial Internet of Things and Industry 4.0. https://doi.org/10.20944/PREPRINTS201 903.0094.V1

Radanliev, P., Rowlands, H., \& Thomas, A. (2014). Supply Chain Paradox: Digital Architecture for Sustainable Strategy Formulation. In R. Setchi, R. J. Howlett, M. Naim, \& H. Seinz (Eds.), Cardiff: Sustainable Design and Manufacturing 2014, Part 2, International Conference (pp. 839-850). Cardiff: Future Technology Press.

Taylor, P., Allpress, S., Carr, M., Lupu, E., Norton, J., Smith, L., Blackstock, J., Boyes, H., Hudson-Smith, A., Brass, I., Chizari, H., Cooper, R., Coulton, P., Craggs, B., Davies, N., De Roure, D., Elsden, M., Huth, M., Lindley, J., Maple, 


\section{Petar Radanliev}

Architectures for Green-Field Supply Chain Integration

Supply Chain Integration Design

C., Mittelstadt, B., Nicolescu, R., Nurse, J., Procter, R., Radanliev, P., Rashid, A., Sgandurra, D., Skatova, A., Taddeo, M., Tanczer, L., Vieira-Steiner, R., ... R.J.,
Westbury, P. S. (2018). Internet of Things realising the potential of a trusted smart world. London. 